\title{
A Critical Edition and Philological Analysis of the Second Chapter of Deutero-Isaiah (Isa 41) on the Basis of the Coptic Manuscript sa 52 (M 568) in Light of Other Coptic Manuscripts Written in the Sahidic Dialect and the Greek Text of the Septuagint
}

\author{
TOMASZ BARTŁOMIEJ BĄK \\ Institute of Biblical Studies, John Paul II Catholic University of Lublin \\ e-mail: tomciobak@gmail.com \\ ORCID: 0000-0003-0328-0282
}

\begin{abstract}
The paper contains a critical edition and philological analysis of the second chapter of Deutero-Isaiah worked out on the basis of the Coptic manuscript sa 52.2 and other available manuscripts written in the Sahidic dialect. Firstly, it presents general information on the fragment of codex sa 52 containing the text of Isa 41. It is followed by a list of brief characteristics of the remaining witnesses that include at least some verses of the second chapter of Deutero-Isaiah. The most important part is a presentation of the Sahidic text of Isa 41, its translation into English and tables of linguistic differences between the text of the LXX and its Coptic rendering. The last part explains difficult philological questions observed in the Coptic text. The focus will be on Isa 41:11-27 since they appear only in manuscript 52.2 and have not been published so far.
\end{abstract}

Keywords: Coptic, Sahidic dialect, the Book of Isaiah, Deutero-Isaiah, sa 52 (M 568), edition of Isa 41

$\mathrm{T}$ his paper presents a critical edition and philological analysis of the second chapter of Deutero-Isaiah on the basis of the Coptic manuscript sa 52 (M 568) and other available Sahidic texts. Manuscript sa 52 (M 568), ${ }^{1}$ belonging to the Pierpont Morgan Collection in New York, has not had a critical edition so far. Its first part, the so-called Proto-Isaiah (Isa 1-39) was the subject of my doctoral dissertation, ${ }^{2}$ which will soon be published in English. Chapter 40 has been published in The Biblical Annals. ${ }^{3}$ The subsequent chapters (41-66) are still to be

1 In the contemporary database of Coptic manuscripts, our manuscript has been registered as CLM 205 (see https://atlas.paths-erc.eu/manuscripts/205 [access: 7.11.2019])

2 The publication of its excerpt: T. Bąk, Il Proto-Isaia in copto-saidico. Edizione critica sulla base di sa 52 (M 568) e di altri testimoni (Roma: Pontificio Instituto Biblico, Facoltà Orientalistica 2014).

3 T. Bąk, „A Critical Edition and Philological Analysis of the First Chapter of Deutero-Isaiah (Isa 40) on the Basis of the Coptic Manuscript sa 52 (M 568) in Light of Other Coptic Manuscripts Written in 
investigated. This paper aims at filling in this gap through publishing the second chapter of Deutero-Isaiah. The present work is based on the photographic edition - the so-called facsimile - which since 1922 has been housed in the Vatican Library, and on the microfilm sent to me by the Morgan Library in New York. In 2016, the Coptic collection of the Morgan Library was made accessible to every interested person at https://archive.org/details/PhantoouLibrary. ${ }^{4}$

The methodology of this paper follows the scheme applied in the publication of Isa 40. In the first part, general information is presented on the text of Isa 41 included in manuscript sa $52 .{ }^{5}$ Then we are going to present other manuscripts written in the Sahidic dialect where at least some verses of the second chapter of Deutero-Isaiah can be found. The main part is a presentation of the Coptic text of Isa 41 along with its critical apparatus including the different readings of the other manuscripts. In turn, the next part contains a translation of the Coptic text into English whose footnotes refer to the particular tables showing language differences in paragraph five. The final section is dedicated to analyses of the more difficult linguistic problems regarding selected verses of the second chapter of Deutero-Isaiah.

\section{General Information}

The text of the second chapter of Deutero-Isaiah begins in manuscript sa 52 (M 568) with the fifth line of the left column on the page marked with the Coptic numeral $\overline{\pi \boldsymbol{\Delta}}(=84)$ and ends in line 31 of the right column on page $\overline{\pi \boldsymbol{S}}(=86)$. In the facsimile edition, Isa 41 begins on the page marked as " $82 \mathrm{M} 568 \mathrm{f.} 40^{\mathrm{v} \text { " and }}$ ends on " 84 M 568 f. $41^{v}$." In total, the text of this chapter is written on ca. six columns. The parchment of the manuscript is of a poor quality. On page $82 \mathrm{M} 568$ f. $40^{v}$ (Coptic $\overline{\Pi \Delta}$ ), there is quite a large hole in the parchment causing that the four lines of the text (Isa 41:4) must have been shortened. Moreover, on 83 M 568 f. $41^{\mathrm{r}}$ and $84 \mathrm{M} 568 \mathrm{f}$. $41^{\mathrm{v}}$ (Coptic $\overline{\boldsymbol{\pi} \boldsymbol{\epsilon}}$ and $\overline{\boldsymbol{n}} \overline{\boldsymbol{Z}}$ ), one can see a double perforation that is, however, located in the lower part of the folio and does not reduce the text.

The columns are irregular. They contain different amounts of text and include $34,35,34,34,35$ and 36 lines respectively. Additionally, under the right column

the Sahidic Dialect and the Greek Text of the Septuagint," BibAn 9/1 (2019) 73-100.

4 The discussed verses of Isa 41 begin at: https://archive.org/stream/PhantoouLibrary/m568\%20Combined $\% 20 \% 28$ Bookmarked\%29\#page/n81/mode/2up [access: 7.11 .2019$]$ ]. Now we can also see the facsimile colour edition at: http://coptot.manuscriptroom.com/manuscript-workspace [access: 7.11.2019].

5 Detailed information on the manuscript can be found in: T. Bąk, „Koptyjski przekład Iz 1-39 w manuskrypcie sa 52 (M 568) z VIII w.," BibAn 5/2 (2015) 289-305. 
on page 83 (Coptic $\overline{\pi \epsilon}$ ) three letters were written: KoY (underlined) to end the construction NC€м€КмOYKOY. The size of the letters and the length of particular lines are different, which is characteristic of the whole manuscript sa 52 (M 568).

The shape of the letters in the whole manuscript sa 52 (M 568) can suggest that the text was written by one scribe. The letter $\mathbf{N}$ has been written in a characteristic way. If it appears at the end of a line, the scribe sometimes uses a simplified notation, i.e. only one horizontal stroke. In Isa 41, this phenomenon occurs four times:

- v. 5: $€ 20 \bar{Y}^{-}$instead of $€ 20 Y \mathrm{~N}$,

- v. 12: the first negation $\mathrm{d}^{-}$instead of $\mathrm{dN}$,

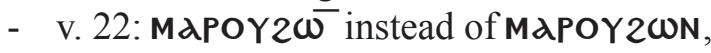

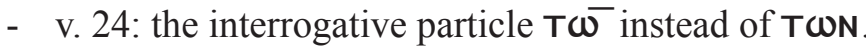

However, the author does not use this notation consistently. Sometimes he writes the regular form of $\mathbf{N}$ at the end of a line. ${ }^{6}$ It is worth noting that where at the end of a line there is $\overline{\mathbf{N}}$, it is never written in the form of a supralinear stroke. ${ }^{7}$

A characteristic of the manuscript is the abbreviated forms of some words. In Isa 41 this principle concerns two proper names: $\overline{\Pi{ }^{I H} \lambda^{8}}$ and $\Theta \mathbf{I} \overline{\lambda H M}$ (v. 27). The author constantly uses these forms of the words "Israel" and "Jerusalem." This feature, called nomina sacra, could be found overall in the Coptic (and also Greek) MSS. ${ }^{9}$

From time to time we can see differently shaped, enlarged initials on the left side of the columns. An excellent example of this is the letter d. If it appears on the left side of the column, its upper part is considerably lengthened and formed as a vertical stroke, sometimes extending over the preceding line of the text. ${ }^{10} \mathrm{~A}$ similar phenomenon can be observed in the notation of the letter $\Delta$ although here its upper extension is not so visible. ${ }^{11}$

Because of the scriptio continua the enlarged letter does not necessarily mark a new sentence. It only suggests that a new thought is introduced somewhere in this context. This can be easily observed, for example, in Isa 41:8 commencing

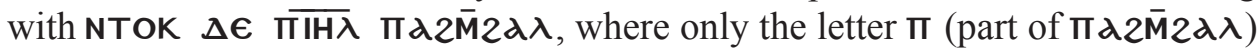
is bigger than the other letters and has been put on the left side of the column. In fact, we have 50 enlarged initials in the whole chapter 41 . Thus it is clear that the

6 See, e.g., 82 M 568 f. $40^{v}$ left column, lines 26, 32, 33; right column, line 8.

7 See, e.g., 82 M 568 f. $40^{v}$ left column, lines 17; 83 M 568 f. $41^{\mathrm{r}}$ left column, line 20, right column, line 13 .

8 Verses 8, 14, 16, 17, 20.

9 See, e.g., L. Hurtado, The Earliest Christian Artifacts: Manuscripts and Christian Origins (Grand Rapids, MI: Eerdmans 2006) 95-134.

10 See, e.g., 82 M 568 f. $40^{v}$ left column, line 21; right column, lines 9, 27, 29; 82 M 568 f. $41^{\text {r }}$ left column, lines 1, 22, 29.

$11 \quad$ See 83 M 568 f. $41^{\text {r }}$ right column, line 9. 
number is much bigger than the number of verses that appeared in the traditional, later division of the text. Further, in the whole chapter each initial is accompanied by a coronis resembling an exclamation mark (sometimes without a dot) or obelus (mathematical sign of division: $\div$ ). A few letters have an asteriscus (interestingly, they are only on 83 M $568 \mathrm{f} .41^{\mathrm{r}}$ ). Dots placed in the middle of the line or at its end help us divide and read the text. It is also worth noting that such signs as coronis, obelus or asteriscus as well as marginal initials were initially written in black ink. Later, however, they were corrected in red.

One of the characteristic notations that appear in our manuscript is the doubling of the letter $\mathbf{N}$, most likely for phonetic reasons. An example of this is Isa 41:2, where sa 52 reads: $2 \overline{\mathbf{N}} \overline{\mathbf{N}} \mathrm{MM} \boldsymbol{d} \mathbf{N} \boldsymbol{N}$, while other witnesses (e.g. sa 41.13) have the correct grammatical wording: $2 \overline{\mathrm{N}} \overline{\mathrm{M}} \mathrm{Md} \overline{\mathrm{N}} \boldsymbol{})_{d}$ ("in the east"; lit. "at the places of the east"). Similarly, in Isa 41:25, manuscript sa 52 reads $2 \mathbf{N}$ NMMd, adding another $\mathbf{N}-$ probably for phonetic reasons. In this edition, it has been marked as 2N $\{\mathbf{N}\}$ MMd.

The inconsistence in the notation of $\mathbf{N}$ - can also be seen in the verses where it was used to express belonging. For example, in Isa 41:25, we first see NK€Pдм€YC (where $\mathbf{N}-$ means "belonging to") and then MK€PAM€YC (instead of

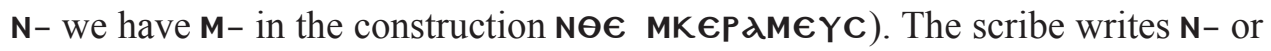
$\mathbf{M}$ - before the same noun $K \in P A M € Y C$ occurring in the same verse.

Another feature of sa 52 is the additional vowel $\boldsymbol{\epsilon}$, added most likely for phonetic reasons. An example of this is Isa 41:2, where our manuscript reads мпємто, while sa 41.13 contains the abbreviated version $\overline{\mathbf{M}} \mathbf{M} \mathbf{M}$ Tо ("before"). The longer version is by all means correct. The Coptic language often uses an additional vowel, especially before two consonants that follow it (as in the case of -MT-). Another example can be found in v. 7, which reads $2 \in \mathbf{N}$, while sa 41.13 has the abbreviated form $2 \overline{\mathbf{N}}$. Similarly, in v. 9 in sa 52 we read $\overline{\mathbf{M}} \pi \epsilon$ IKגdK, whereas in sa 41.13 we find the abbreviated Mmikdak.

Manuscript sa 52 is also characterised by certain negligence in writing the borrowings from Greek. For example, in Isa 41:6 the author correctly writes the verb вонөє . But a few verses further (Isa 41:14) in the same word one letter is missing: BHө€І.

Although the scribe did not write in a very diligent way, there are not many words where the letters were corrected. Only in Isa 41:17, in aNOK пє пхоєic חNOYT€ the article ח (in TNOYT€) was firstly written as $\mathbf{N}$ (of the plural or nota relationis). The other verses do not betray any traces of correction. 


\section{List of Manuscripts with the Text of Isa 41 in the Sahidic Dialect of the Coptic Language}

The selected verses from the second chapter of Deutero-Isaiah can be found only in three manuscripts ${ }^{12}$ :

Sa 41.13: one parchment folio containing the text of Isa 40:24-41:10a. Currently, it is housed in London as BL, Or. 3579 A. 30, fol. 2. Our text of Isa 41:1-10 is partly (verses 1-2a) on the recto, and partly on the verso (verses $2 \mathrm{~b}-10 \mathrm{a})$. In the original numbering of the manuscript, the recto bears number $\overline{\mathbf{c}} \overline{\boldsymbol{\Gamma}}(=93)$, while the verso $-\overline{\mathbf{q}} \overline{\boldsymbol{\Delta}}(=94)$, which testifies to the fact that manuscript sa 41.13 belongs to a larger codex. ${ }^{13}$ The edition of manuscript sa 41.13 was worked out by Schleifer ${ }^{14}$ and Winstedt. ${ }^{15}$ In the case of differences between the two editions, Schleifer's study seems to be more reliable. ${ }^{16}$

Sa 212 ${ }^{\mathrm{L}}$.12: the manuscript from the White Monastery in Sohag is part of a large lectionary consisting of over three hundred parchment pages. The fragment with Isa 40:26-31 and our verse Isa 41:1 belong to the part that consists of four folios of ca. $34 \times 27 \mathrm{~cm}$, housed in the Vatican Library in Rome (Rom, BV, Borgia copto 109, cass. $X$, fasc. 32, fol. 6-9). It most likely comes from the 11 th century and contains short fragments of various Old Testament books, which were to be read on any day of the liturgical year. ${ }^{17}$ The edition of Isa 41:1 was prepared by Ciasca, who marked it with number XXXII. ${ }^{18}$

CLM 1604: this text was not included in Schüssler's work. But it can be found on Nagel's list, ${ }^{19}$ catalogued as: Kairo, AegMus 44. 674. 131. Nagel also

12 During the international conference entitled "Coptic Literature in Context. The Contexts of Coptic Literature," held in Rome on 25-27 February 2019, A. Delattre spoke about a fragment of the parchment codex that has been discovered at Antinoupolis, containing the text of Isa 41-42. The manuscript has not been published yet. In CLM (Coptic Literary Manuscript) the manuscript has been catalogued as 6411 (see https://atlas.paths-erc.eu/manuscripts/6411 [access 7.11.2019]).

13 More information on manuscript sa 41.13 in: Bąk, Isa 40, 76-77.

14 J. Schleifer, Sahidische Bibel-Fragmente aus dem British Museum zu London (Sitzungsberichte der Kaiserlichen Akademie der Wissenschaften in Wien. Philosophisch-Historische Klasse 162/6; Wien: Hölder 1909) 9-12.

15 E.O. Winstedt, „Some Unpublished Sahidic Fragments of the Old Testament,” JTS 10 (1909) 244-246.

16 Winstedt („Some Unpublished Sahidic Fragments,” 233) himself writes about the imperfections of his edition: "The faulty and incomplete decipherment of some of the more illegible fragments will, I hope, be excused, as my time was on both occasions limited to a few hours, and I have had no opportunity of revising my copies".

17 More information on sa 212L.12 in: Bąk, Isa 40, 78-79.

18 A. Ciasca, Sacrorum Bibliorum fragmenta copto-sahidica Musei Borgiani iussu et sumptibus S. Congregationis de Propaganda Fide studio P. Augustini Ciasca ordinis Eremitarum S. Agostini edita (Roma: Typis S. Congregationis de Propaganda Fide 1889) II, 240.

19 P. Nagel, „Editionen koptischer Bibeltexte seit Till 1960,” APF 35 (1990) 60. 
gives the reference to the edition worked out by Crum. ${ }^{20}$ In the CLM system (Coptic Literary Manuscript) it has been catalogued as 1604, and this number has been used in this paper. ${ }^{21}$ The text was discovered in the Monastery of Epiphanius at Thebes, ${ }^{22}$ written on limestone. ${ }^{23}$ It contains only the two last verses of the second chapter of Deutero-Isaiah, i.e. Isa 41:28-29. They are preceded by $\epsilon \mathbf{C d} \epsilon \mathbf{I d C}$ ("Isaiah").

In order to illustrate the contents of particular manuscripts better, the occurrence of the verses from Isa 41 is presented in the table where:

- an " $x$ " means the occurrence of the whole verse,

- an "(x)" means the occurrence of only a fragment of a given verse,

- an empty space in the table means the lack of a given verse in the manuscript.

The contents of the manuscripts are as follows:

\begin{tabular}{|l|c|c|c|c|c|c|c|c|c|c|c|c|c|c|c|}
\hline & 1 & 2 & 3 & 4 & 5 & 6 & 7 & 8 & 9 & 10 & 11 & 12 & 13 & 14 & 15 \\
\hline Sa 41.13 & $\mathrm{x}$ & $\mathrm{x}$ & $\mathrm{x}$ & $\mathrm{x}$ & $\mathrm{x}$ & $\mathrm{x}$ & $\mathrm{x}$ & $\mathrm{x}$ & $(\mathrm{x})$ & $(\mathrm{x})$ & & & & & \\
\hline Sa 212 .12 & $(\mathrm{x})$ & & & & & & & & & & & & & & \\
\hline CLM 1604 & & & & & & & & & & & & & & & \\
\hline
\end{tabular}

\begin{tabular}{|l|c|c|c|c|c|c|c|c|c|c|c|c|c|c|}
\hline & 16 & $\mathbf{1 7}$ & $\mathbf{1 8}$ & $\mathbf{1 9}$ & $\mathbf{2 0}$ & $\mathbf{2 1}$ & $\mathbf{2 2}$ & $\mathbf{2 3}$ & $\mathbf{2 4}$ & $\mathbf{2 5}$ & $\mathbf{2 6}$ & $\mathbf{2 7}$ & $\mathbf{2 8}$ & $\mathbf{2 9}$ \\
\hline Sa 41.13 & & & & & & & & & & & & & & \\
\hline Sa 212 .12 & & & & & & & & & & & & & & \\
\hline CLM 1604 & & & & & & & & & & & & & $x$ & $x$ \\
\hline
\end{tabular}

The table clearly shows that so far only 12 verses of Isa 41 have been published. The remaining 17 verses are exclusively in our manuscript sa 52, whose edition constitutes the subject of this paper.

20 W.E. Crum - H.G. Evelyn White, The Monastery of Epiphanius at Thebes. II. Coptic Ostraca and Papyri Edited with Translations and Commentaries by W.E. Crum. Greek Ostraca and Papyri Edited with Translations and Commentaries by H.G. Evelyn White (New York: The Metropolitan Museum of Art 1926) 7 (No. 29).

21 See https://atlas.paths-erc.eu/manuscripts/1604 [access 7.11.2019]. In LDAB (Leuven Database of Ancient Books) the manuscript has been catalogued as 112538 (https://www.trismegistos.org/ldab/ text.php?quick=112538 [access 7.11.2019]).

22 More information on the monastery, the monks' lives and their writing activities in: W.E. Crum H.E. Winlock, The Monastery of Epiphanius at Thebes. I. The Archaeological Material by H.E. Winlock. The Literary Material by W.E. Crum (New York: The Metropolitan Museum of Art 1926).

23 Crum, Coptic Ostraca, 158. 


\section{The Sahidic Text of Isa 41}

In the edition of the text of Isa 41, the following signs have been used:

$-<>$ pointed brackets have been used when the copyist omitted certain letters that should be added for a proper understanding of the text,

- \{\} braces appear in these places where the scribe, perhaps as a result of wrong dittography, wrote letters that seem redundant,

$->$ indicates the lack of a given form in the manuscript whose number is given next to it;

- (N) indicates the places where the letter $\mathbf{N}$, occurring at the end of the line, was signalised by a stroke,

- an exclamation mark in superscript: ' suggests a more correct reading.

The text of Isa 41 in the Sahidic dialect of the Coptic language reads as follows:

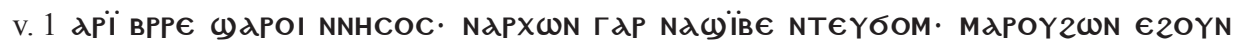

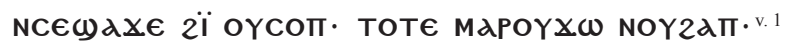

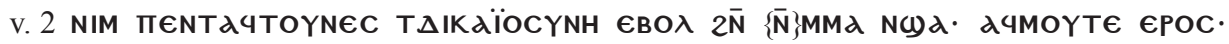

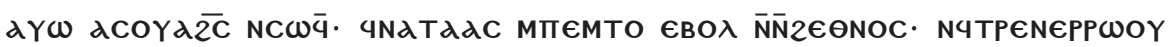
P $\epsilon \curlyvee 2 H \lambda \epsilon B O \lambda \cdot$ v. 2

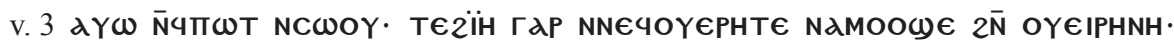

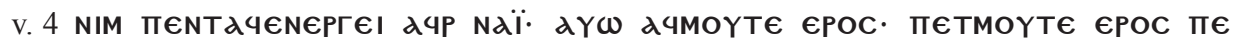

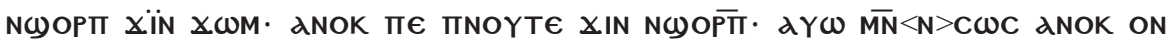
$\pi \epsilon \cdot$ v. 4

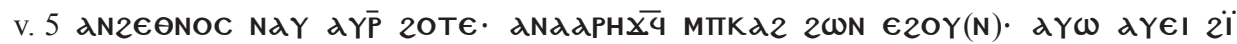
OYCOT .

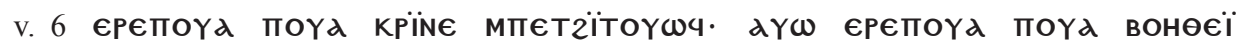
$\epsilon \Pi € 4 C O N \cdot$ dYW YNAXOOC $X €$

v. 1 NT€үбом (= sa 212L.12): $2 \overline{\mathrm{N}}$ т€Үбом sa 41.13

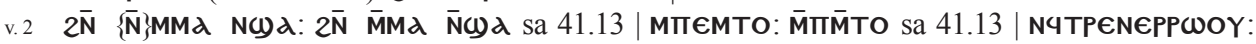

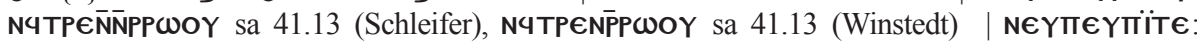

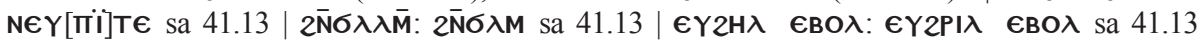
(Winstedt)

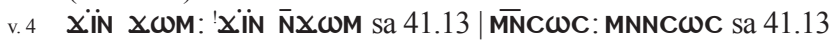




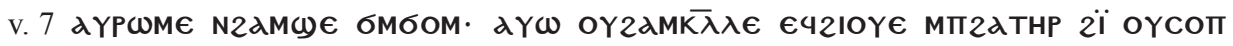

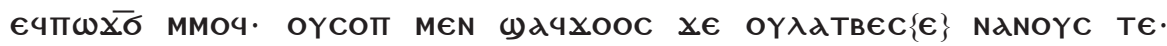

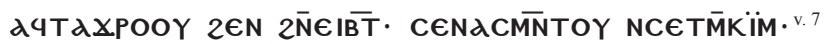

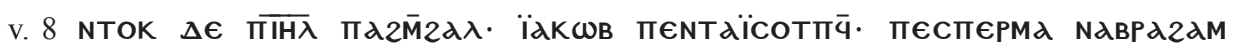

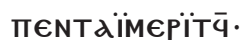

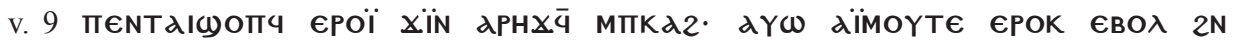

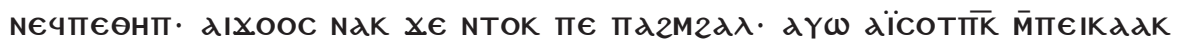
NCWïv.9

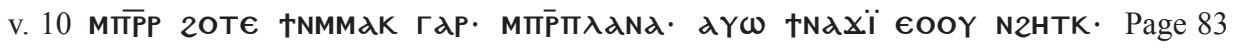

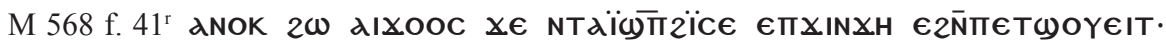

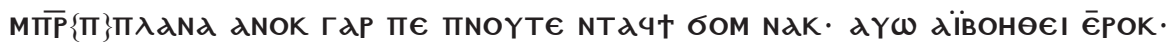

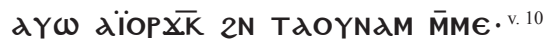

v. 11 €IC2HHT€ CENAXї

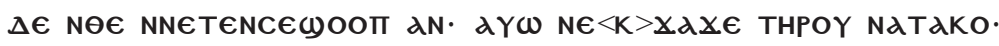

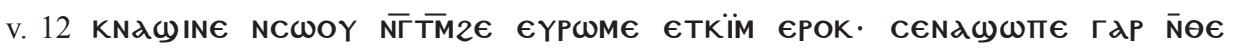

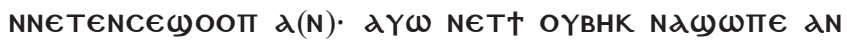

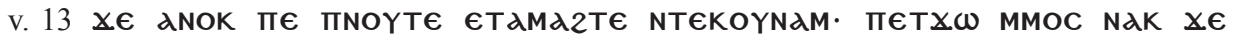

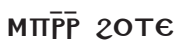

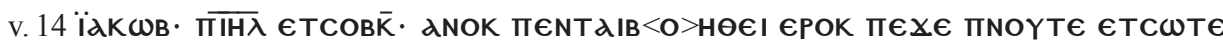

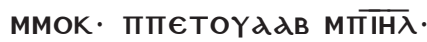

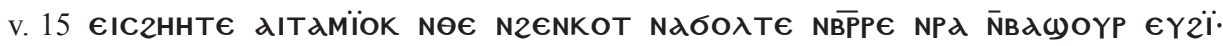

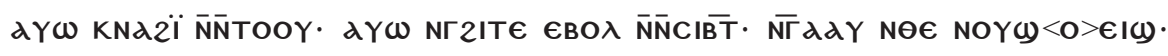

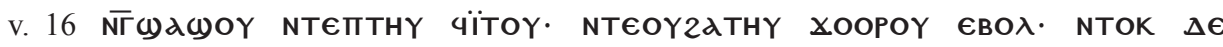
$\overline{\mathrm{KN}} \lambda €$

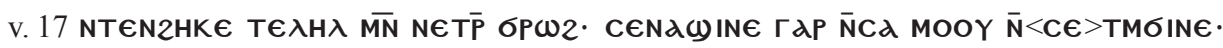

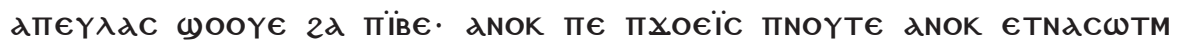

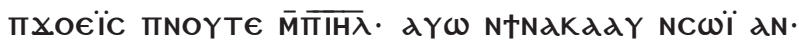

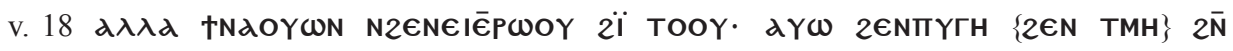

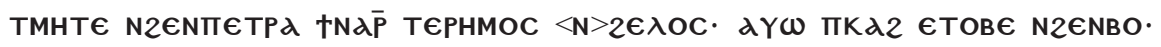

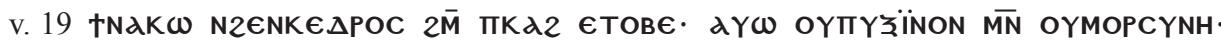
MN OYKYாגPÏCOC. MN OYா€YKH.

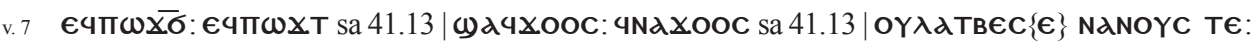

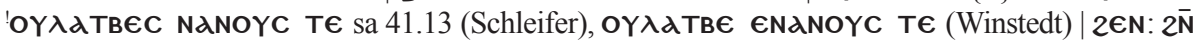
sa 41.13

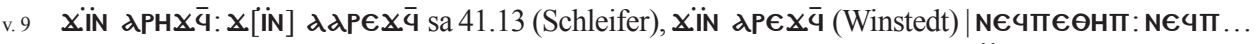

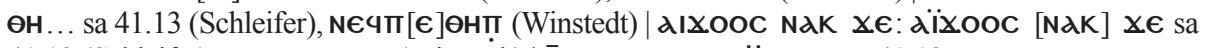

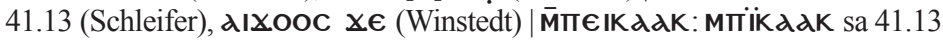

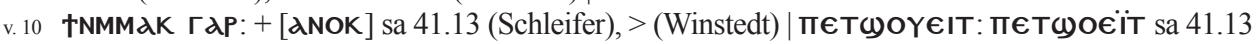




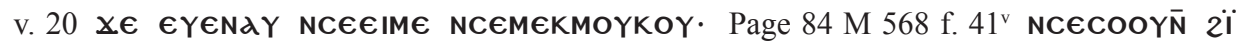

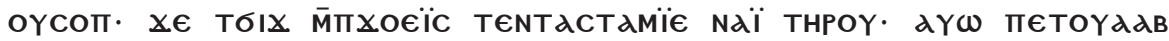

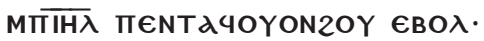

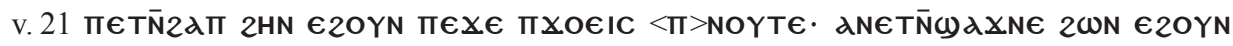

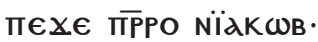

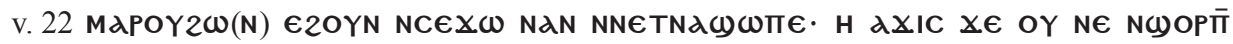

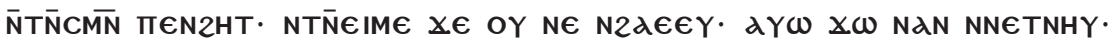

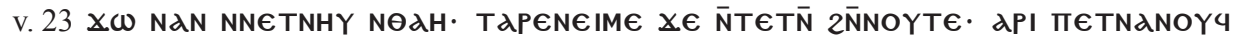

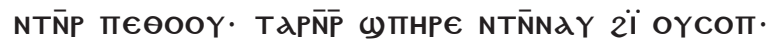

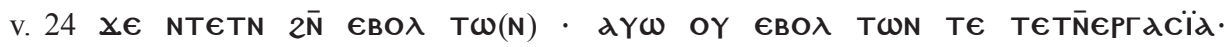

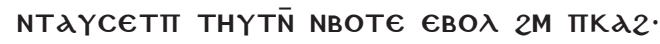

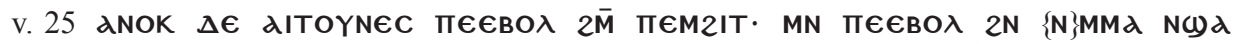
MTPH. CENAMOYTE EPOOY $2 M$ TIPAN. MAPENAPXWN EI. AYW NE€ NOYOME

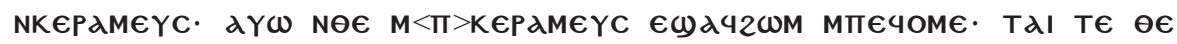
ETOYNA2 $\bar{M}$ THYT $\bar{N}$.

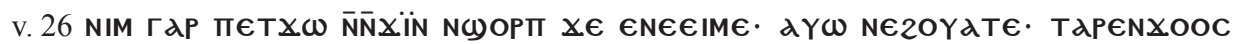

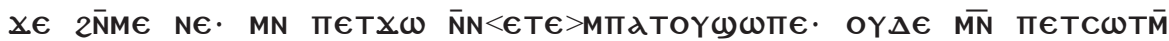
$\epsilon N \epsilon T \bar{N} \omega \lambda X \epsilon \cdot$

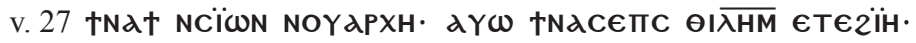

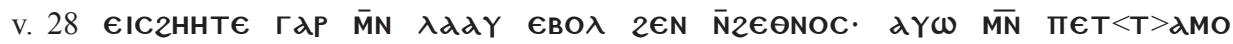

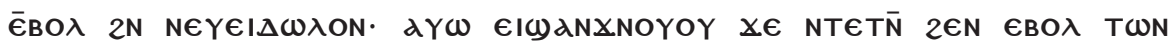
NNEYOYOWBET. v. 28

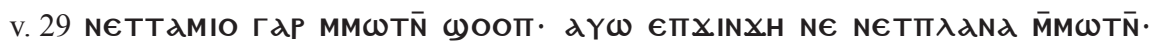

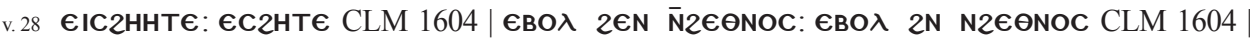

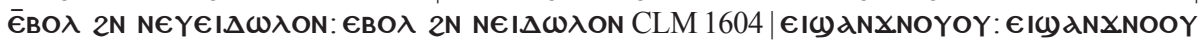
CLM 1604 


\section{An English Translation of the Sahidic Text}

In translating the Coptic text of Isa 41 into English I have used NETS. ${ }^{24}$ The text of the Septuagint, being the basis of my philological investigations, has been taken from the critical edition by Ziegler. ${ }^{25}$

The English translation of Isa 41 from the Sahidic dialect of the Coptic language is as follows:

v. 1 Renew yourselves for me, ${ }^{26} \mathrm{O}$ islands, for the rulers will change their ${ }^{27}$ strength; let them approach and speak together; then let them declare judgment.

v. 2 Who has roused righteousness from the east, ${ }^{28}$ called it and it followed him ${ }^{29}$ ? He will place $\mathrm{it}^{30}$ before nations and astonish kings, and he will place their daggers in the earth, ${ }^{31}$ and their bows like brushwood that is driven out. ${ }^{32}$

v. 3 And he will pursue them, for ${ }^{33}$ the way of his feet will walk $^{34}$ in peace. ${ }^{35}$

v. 4 Who has wrought, done ${ }^{36}$ these things and $d^{37}$ called her ${ }^{38}$ The one calling her $i s^{39}$ at the beginning from generations. ${ }^{40}$ I am God from the beginning, ${ }^{41}$ and afterward I am as well. ${ }^{42}$

v. 5 The nations saw and became afraid; those of the end ${ }^{43}$ of the earth drew near and came together,

24 My motives to use NETS as well as other introductory remarks to the English translation are the same as in the analysed text of Isa 40 (See Bąk, Isa 40, 84).

25 Ziegler, J. (ed.), Septuaginta. Vetus Testamentum Graecum. Auctoritate Societatis Litterarum Gottingensis editum. XIV. Isaias (Göttingen: Vandenhoeck \& Ruprecht 1939).

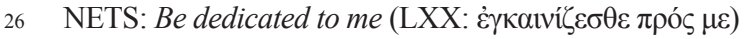

27 Om. in NETS $\rightarrow$ T 1

28 Copt. lit. from the places of rising

29 NETS: to its feet and it will go $\rightarrow \mathrm{T} 2$, T 3

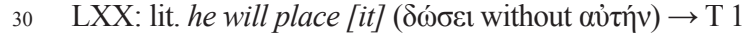

31 Lit. upon the earth $\rightarrow \mathrm{T} 4$

$32 \rightarrow \mathrm{T} 6$

33 NETS: and $\rightarrow \mathrm{T} 1$, T 2

34 NETS: pass through $\rightarrow \mathrm{T} 3$

$35 \rightarrow$ T 6

36 NETS: and done $\rightarrow \mathrm{T} 2$

37 Om. in NETS $\rightarrow$ T 1

38 Or: called it. V. 4a in NETS: Who has wrought and done these things? The one calling her from the beginning of generations has called her.

Om. in NETS $\rightarrow$ T 1

NETS: from the beginning of generations $\rightarrow \mathrm{T} 7$

NETS: I, God, am first $\rightarrow$ T 1

NETS: and for the things that are coming, I am $\rightarrow$ T 1, T 3

NETS: the ends $\rightarrow \mathrm{T} 7$ 
v. 6 each judging ${ }^{44}$ his $^{45}$ neighbor, and each ${ }^{46}$ helping his ${ }^{47}$ brother. ${ }^{48}$ And he will say:

v. 7 The $^{49}$ carpenter $^{50}$ has become strong, also the ${ }^{51}$ smith as he smites with the hammer while at the same time making it flat $t^{52}$. At some time, he $s a y s^{53}$ : "The seam is good"; he hs $^{54}$ strengthened them with nails; they will set them up, and they will not be moved.

v. 8 But you, Israel, my servant, Iakob, whom I have chosen, the offspring of Abraam, whom I have loved,

v. 9 you ${ }^{55}$ whom I took hold of for myself ${ }^{36}$ from the end $d^{57}$ of the earth, and I called you from its hidden places ${ }^{58}$ and $^{59}$ I said to you, "You are my servant and ${ }^{60} \mathrm{I}$ have chosen you and ${ }^{61}$ not forsaken you";

v. 10 do not fear, for I am ${ }^{62}$ with you; do not wander off. In you I will be glorified. But I said: "I have laboured vainly [and] for empty things. Do not wander off, ${ }^{63}$ for I am God ${ }^{64}$ who has strengthened you, and I have helped you, and I have made you secure with my righteous right hand.

v. 11 See, all who oppose you shall be ashamed and disgraced, for ${ }^{65}$ they shall be as though they were not, and all your adversaries shall perish. ${ }^{66}$

v. 12 You shall seek them, but you shall not find the $\mathrm{men}^{67}$ who shall treat you violently, for they shall be as though they were not, and those who war against you shall not be ${ }^{68}$

v. 13 because I $\mathrm{am}^{69} \mathrm{God}^{70}$ who holds your right hand, who says to you, "Do not fear,

44 NETS: deciding to help $\rightarrow \mathrm{T} 7$

45 Om. in $\operatorname{LXX}(\tau \tilde{\varphi} \pi \lambda \eta \sigma i ́ o v) \rightarrow \mathrm{T} 1$

46 Om. in NETS $\rightarrow$ T 1

$47 \quad$ Om. in $\operatorname{LXX}(\tau \tilde{\varphi} \dot{\alpha} \delta \varepsilon \lambda \varphi \tilde{\omega}) \rightarrow \mathrm{T} 1$

48 NETS translates this part of the verse: each deciding to help his neighbor and his brother.

49 Lit. $A$ (LXX: $\alpha \dot{v} \eta \dot{\rho}=$ sa 52)

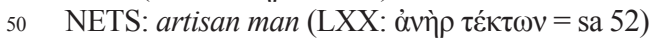

51 Lit. $a(\mathrm{LXX}: \chi \alpha \lambda \kappa \varepsilon v ́ \varsigma=$ sa 52$)$

52 NETS: striking (LXX: غ̇ं $\alpha v ́ v \omega v=\mathrm{sa} 52) \rightarrow \mathrm{T} 1$

53 NETS: he will say $\rightarrow \mathrm{T} 7$

54 NETS: they have $\rightarrow \mathrm{T} 7$

55 Om. in LXX (oṽ)

56 Om. in NETS $\rightarrow$ T 1

57 NETS: the ends $\rightarrow \mathrm{T} 7$

58 NETS: mountain peaks $\rightarrow \mathrm{T} 3, \mathrm{~T} 6$

59 Om. in sa $52 \rightarrow$ T 2

60 Om. in NETS $\rightarrow$ T 1

61 Om. in sa $52 \rightarrow \mathrm{T} 2$

62 Lit. om. in sa $52 \rightarrow \mathrm{T} 2$

63 Om. in NETS $\rightarrow$ T 1

64 NETS: your God $\rightarrow \mathrm{T} 2$

$65 \rightarrow$ T 3

$66 \rightarrow$ T 6

67 Lit. a man $\rightarrow$ T 5 , T 7

$68 \rightarrow$ T 6

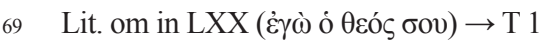

70 NETS: your God $\rightarrow$ T 2 
v. 14 O Iakob, O small Israel." I have helped you, says God who redeems you, the Holy of ${ }^{11}$ Israel.

v. 15 Look, I made you as wheels of cart $^{72}$ new, ${ }^{73}$ saw-shaped [and] threshing ${ }^{74}$ and you shall thresh mountains and grind hills to powder and ${ }^{75}$ make them like dust. ${ }^{76}$

v. 16 And $^{77}$ you shall winnow them, ${ }^{78}$ and $^{79}$ a wind shall take them, and ${ }^{80}$ a tempest shall scatter them. But you shall rejoice in the holy things ${ }^{81}$ of Israel.

v. 17 And $^{82}$ the poor and needy shall be glad, ${ }^{83}$ for they shall seek water and shall not find $[i t]^{84}$; their tongue has been dried up from thirst. ${ }^{85} \mathrm{I}^{a m^{86}}$ the Lord God, I, the Lord $^{87}$, the God of Israel, will listen and I will not forsake them.

v. 18 But I will open rivers on the mountains ${ }^{88}$ and fountains in the midst of rocks ${ }^{89}$; I will make the wilderness into ${ }^{90}$ marshlands and the thirsty land as ${ }^{91}$ watercourses.

v. 19 I will put in ${ }^{92}$ the dry land cedars ${ }^{93}$ and a box tree and a myrtle and a cypress and $a$ pine $e^{94}$.

v. 20 so that together they may see $a n d^{95}$ know and ${ }^{96}$ consider and ${ }^{97}$ understand that the hand ${ }^{98}$ of the Lord has done all these things, and the Holy One of Israel has exhibited them.

v. 21 Your judgement draws near, says the Lord God; your counsels have drawn near, says the king of Jakob.

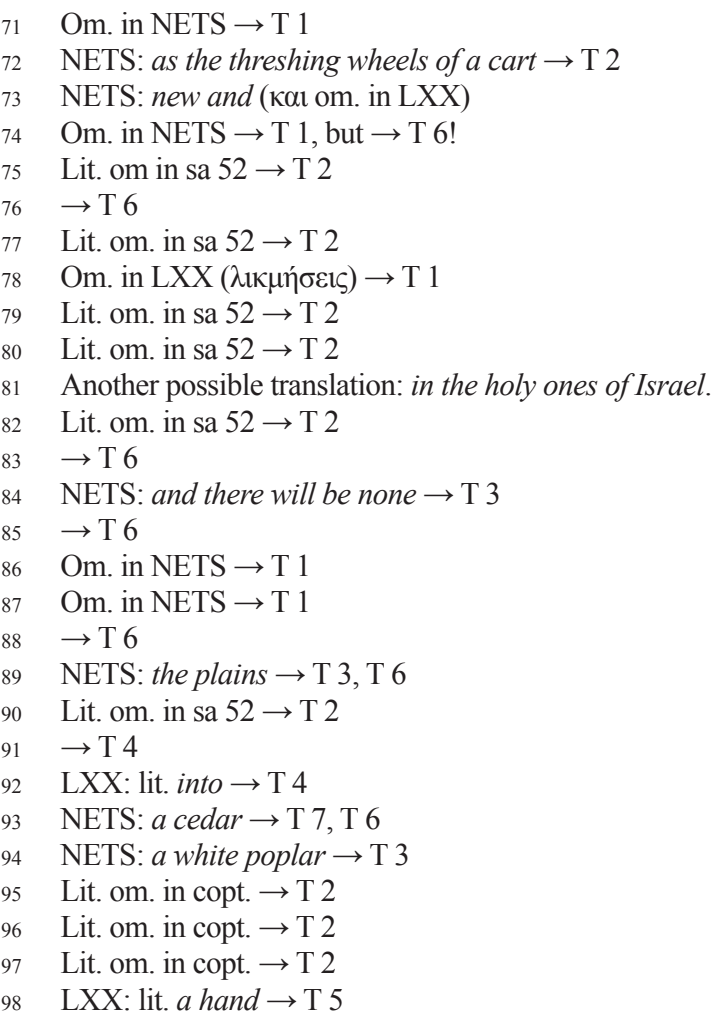


v. 22 Let them draw near and ${ }^{99}$ declare to $u s^{100}$ the things that will happen or speak of the former things, what they were, ${ }^{101}$ and ${ }^{102}$ we will apply our ${ }^{103}$ mind and ${ }^{104}$ know what the last things will be - and tell us the things that are coming. ${ }^{105}$

v. $23 \mathrm{Tell}^{106} u s^{107}$ the things that are coming at the end, and ${ }^{108}$ we will know that you are gods; do good ${ }^{109}$ and $^{110}$ do harm, and ${ }^{111}$ we will wonder as well as see.

v. 24 Because whence are you and whence is ${ }^{112}$ your work? They have chosen you as an abomination from the earth. ${ }^{113}$

v. 25 But I stirred up the one who is from the north and the one who is from the rising of the sun; they shall be called by my name. Let rulers come and like potter's clay - even as a potter treading $h i s^{114}$ clay - so shall you be trodden down.

v. 26 For who shall declare the things that were from the beginning so that we might know them, ${ }^{115}$ and the former things, and ${ }^{116}$ we will say that they are true? There is none who foretells nor any who hears your words.

v. 27 I will give dominion to Sion ${ }^{117}$ and I will comfort Ierousalem on the way

v. 28 For from the nations, behold, no one, ${ }^{118}$ and from among their idols, there was none who declared. ${ }^{119}$ And if I should ask them, Whence are you? They will not answer me,

v. 29 for they are the ones who make you ${ }^{120}$ and those who lead you astray ${ }^{121}$ are $^{122}$ vain.

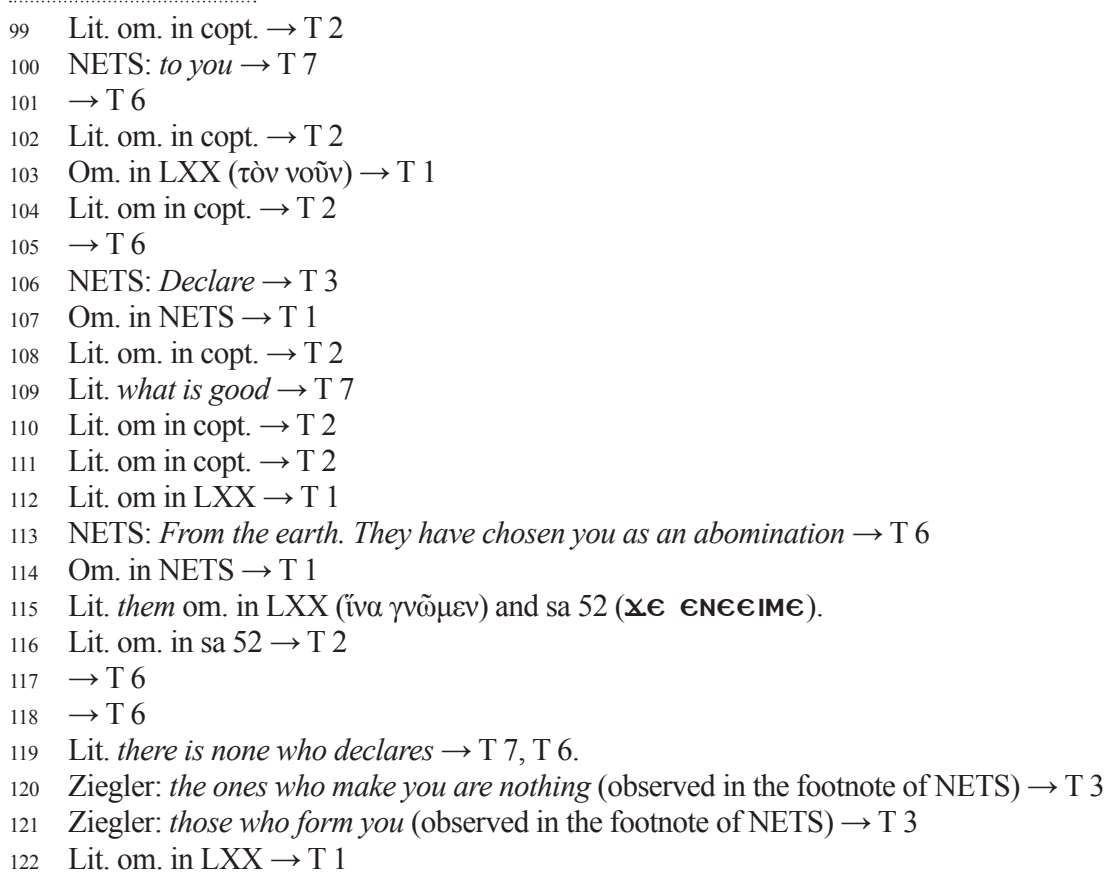




\section{Tables of Language Differences}

The differences between the text of the Septuagint and its Coptic translation will be presented in the following order: additions (Table 1), omissions (Table 2) found in the Coptic text, the use of different vocabulary (Table 3), changes of prepositions (Table 4) and articles (Table 5), ${ }^{123}$ changes in word order (Table 6) ${ }^{124}$ and semantic changes (Table 7). ${ }^{125}$ The last table shows the Greek borrowings appearing in the Coptic text of Isa 41 (Table 8).

Table 1. Additions to the Coptic text

\begin{tabular}{|c|c|c|}
\hline $41: 1$ & i $\sigma \chi v v$ : strength & NT€ Үбом: their strength (> Ziegler) \\
\hline $41: 2$ & $\delta \omega ́ \sigma \varepsilon 1:$ he will place & INATdAC: he will place it (> Ziegler) \\
\hline $41: 3$ & $\eta \dot{\eta}$ óóc: the way & 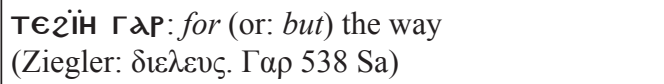 \\
\hline $41: 4$ & 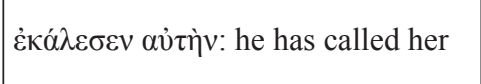 & $\begin{array}{l}\text { АҮ } \omega \text { дчмоҮтє ЄРОС: and he has called her } \\
\text { (> Ziegler) }\end{array}$ \\
\hline $41: 4$ & 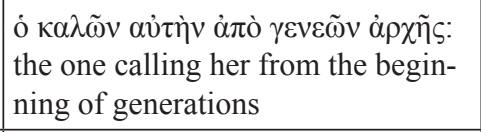 & 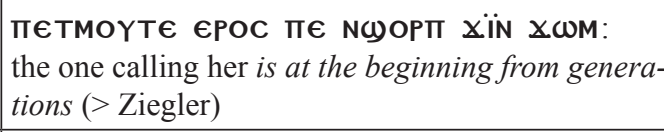 \\
\hline $41: 4$ & $\dot{\varepsilon} \gamma \omega \grave{\omega} \theta \varepsilon o ̀ \varsigma ~ \pi \rho \tilde{\omega} \tau \mathrm{o} \varsigma:$ I, God, am first & 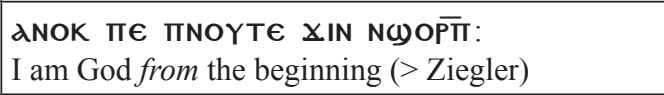 \\
\hline $41: 4$ & 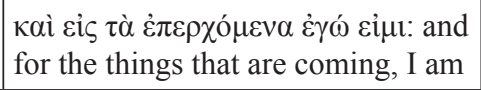 & 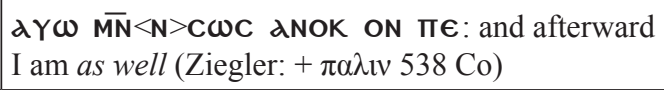 \\
\hline $41: 6$ & $\tau \tilde{\varphi} \pi \lambda \eta \sigma i ́ o v:$ neighbor & 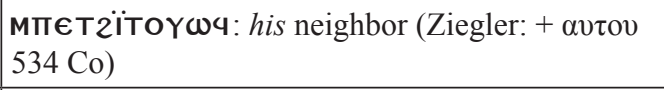 \\
\hline $41: 6$ & $\begin{array}{l}\tau \tilde{\omega} \alpha \delta \varepsilon \lambda \varphi \tilde{\alpha} \beta \text { on } \theta \tilde{\eta} \sigma \alpha 1: \text { to help the } \\
\text { brother }\end{array}$ & 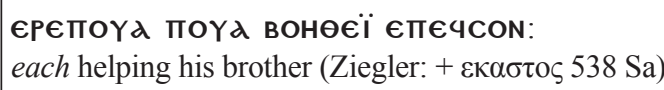 \\
\hline $41: 6$ & 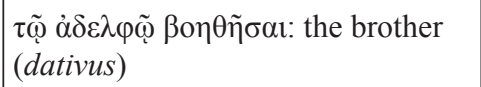 & $\begin{array}{l}€ \Pi € 4 C O N \text { : to his brother (Ziegler: + }+\alpha v \tau o v \\
449 \text { Co) }\end{array}$ \\
\hline
\end{tabular}

123 Omitting or adding an article does not necessarily result from the translator's intention to interfere in the content. It is frequently (especially in Coptic) the semantic rules that decide about the omission of an article. Therefore, it would be no "material" sense to list all the places where the Coptic translation is not faithful to all the articles occurring in the Greek LXX. Table 5 only shows selected examples.

124 The differences in word order do not always have to reflect the real changes introduced by the Coptic translator. They can often depend on the syntactic rules according to which, e.g. the direct object usually appears immediately after the verb (see Isa 41:18.19) (cf. B. Layton, A Coptic Grammar. With Chrestomathy and Glossary. Sahidic Dialect. Second Edition, Revised and Expanded. With an Index of Citations [Wiesbaden: Harrassowitz Verlag 2004], § 182).

125 Here we have included the grammatical and semantic changes (e.g. number, tense, person, gender, etc.). 


\begin{tabular}{|c|c|c|}
\hline $41: 7$ & $\begin{array}{l}\alpha \ddot{\mu} \mu \alpha \dot{\varepsilon} \lambda \alpha v ́ v \omega v: \text { at the same time } \\
\text { striking }\end{array}$ & 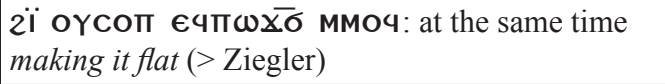 \\
\hline 41:9 & $\begin{array}{l}\text { oũ } \alpha v \tau \varepsilon \lambda \alpha \beta \text { ó } \mu \eta v: \text { whom I took } \\
\text { hold of }\end{array}$ & 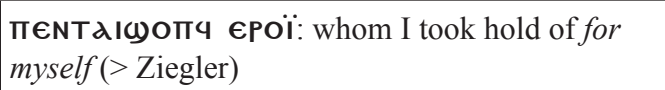 \\
\hline 41:9 & 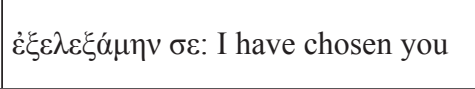 & 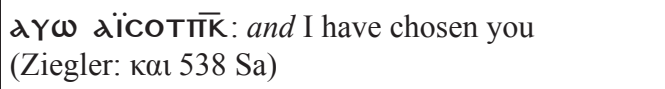 \\
\hline $41: 10$ & $\mu \eta \grave{~} \pi \lambda \alpha \nu \tilde{\omega}:$ do not wander off & 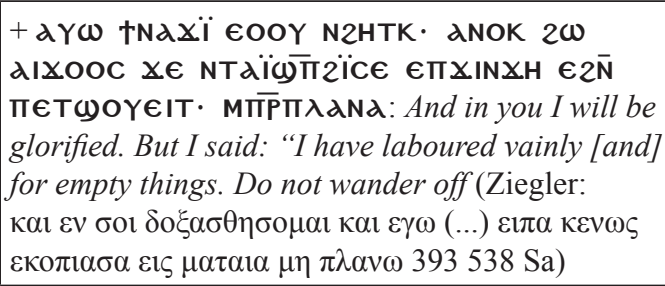 \\
\hline $41: 13$ & 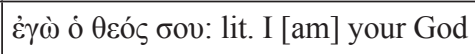 & АNOK пє пNOYT€: I am God (> Ziegler) \\
\hline $41: 14$ & I $\sigma \rho \alpha \eta \lambda^{2}:$ O Israel & 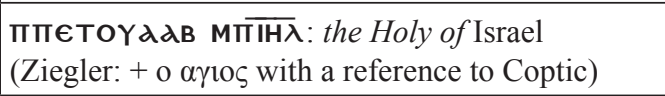 \\
\hline $41: 15$ & 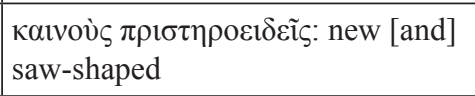 & 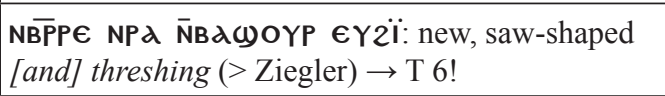 \\
\hline $41: 16$ & 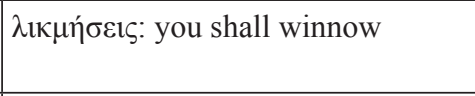 & 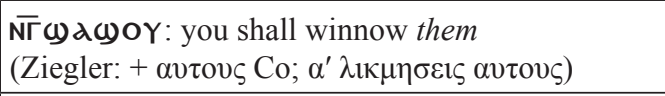 \\
\hline $41: 17$ & 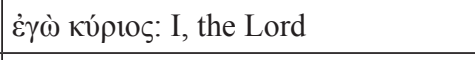 & גNOK $\Pi \epsilon$ пхоєї: I $a m$ the Lord \\
\hline $41: 17$ & ó $\theta \varepsilon$ ò $\varsigma$ I $\rho \alpha \eta \lambda$ : the God of Israel & $\begin{array}{l}\text { пхоєї пNOYт€ } \overline{\mathbf{M}} \overline{\Pi \mathrm{IH} \lambda} \text { : the Lord, the God of } \\
\text { Israel (Ziegler: pr. Kvptos } 198538 \mathrm{Sa} \text { ) }\end{array}$ \\
\hline $41: 22$ & 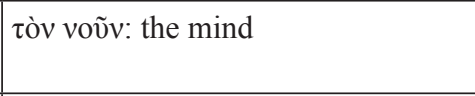 & $\begin{array}{l}\text { пєN2HT: our mind (lit. our heart) } \\
\text { (Ziegler: }+\eta \mu \omega v \text { with a reference to Co) }\end{array}$ \\
\hline $41: 23$ & 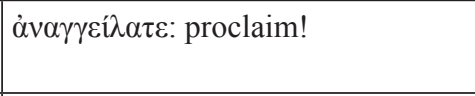 & $\begin{array}{l}X \omega \mathrm{N} d \mathrm{~N} \text { : tell } u s ! \text { (Ziegler: }+\eta \mu \mathrm{tv} \text { with a reference } \\
\text { to Co) }\end{array}$ \\
\hline $41: 24$ & $\begin{array}{l}\pi \text { ó } \theta \varepsilon v \dot{\eta} \dot{\varepsilon} \rho \gamma \alpha \sigma i ́ \alpha \text { v } \mu \tilde{\omega} v: \text { whence [is] } \\
\text { your work? }\end{array}$ & 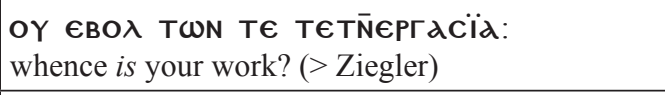 \\
\hline $41: 25$ & 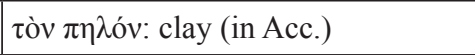 & мпєчомє: his clay (> Ziegler) \\
\hline $41: 29$ & $\mu \alpha ́ \tau \eta v:$ vain & €ாХINXH NG: are vain (> Ziegler) \\
\hline
\end{tabular}


Table 2. Omissions in the Coptic text

\begin{tabular}{|c|c|c|}
\hline $41: 2$ & 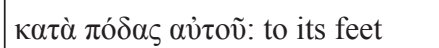 & Om. in sa 52 (> Ziegler) \\
\hline $41: 3$ & $\kappa \alpha i^{2}$ & Lit. om. in sa 52 (> Ziegler) \\
\hline $41: 4$ & $\kappa \alpha i^{1}$ & Lit. om. in sa 52 (> Ziegler) \\
\hline $41: 9$ & $\kappa \alpha i^{2}$ & Lit. om. in sa 52 (> Ziegler) \\
\hline $41: 9$ & $\kappa \alpha i^{3}$ & Lit. om. in sa 52 (> Ziegler) \\
\hline $41: 10$ & $\operatorname{\varepsilon i\mu } \mathrm{1}^{1}$ & Lit. om. in sa 52 (> Ziegler) \\
\hline $41: 10$ & 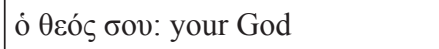 & пNOYT€: God (observed by Ziegler) \\
\hline $41: 13$ & 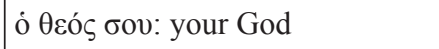 & пNOYT€: God (observed by Ziegler) \\
\hline $41: 15$ & 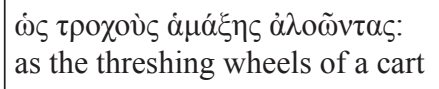 & 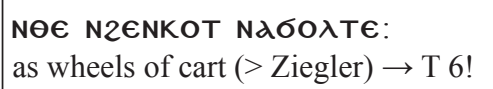 \\
\hline $41: 15$ & $\kappa \alpha i^{3}$ & Lit. om in sa 52 (> Ziegler) \\
\hline $41: 16$ & $\kappa \alpha i^{1,2,3}$ & Lit. om in sa 52 (> Ziegler $)$ \\
\hline $41: 17$ & $\kappa \alpha i^{1}$ & Lit. om in sa 52 (> Ziegler) \\
\hline $41: 18$ & 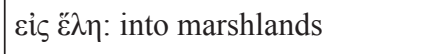 & $<\mathbf{N}>2 € \mathbf{\epsilon}$ OC: marshlands ( $>$ Ziegler) \\
\hline $41: 20$ & $\kappa \alpha i^{1,2,3}$ & Lit. om in sa 52 (> Ziegler $)$ \\
\hline $41: 22$ & $\kappa \alpha i^{1,2,3}$ & Lit. om in sa 52 (> Ziegler $)$ \\
\hline $41: 23$ & $\kappa \alpha i^{1,2,3}$ & Lit. om in sa 52 (> Ziegler) \\
\hline $41: 26$ & $\kappa \alpha i^{2}$ & Lit. om in sa 52 (> Ziegler) \\
\hline
\end{tabular}

The table shows the places where the Greek кai was not translated by the Coptic $d Y \omega$ or $\mathbf{M N}$. This does not, however, mean that it was not expressed otherwise, e.g. by using conjunctive, in accordance with the syntax of the Coptic language. 
Table 3. Changes of words

\begin{tabular}{|c|c|c|}
\hline $41: 2$ & $\dot{\alpha} \pi$ ò $\dot{\alpha} v \alpha \tau \mathrm{O} \lambda \tilde{\omega} v$ : from the east & $\begin{array}{l}\Theta B O \lambda 2 \overline{\mathbf{N}}\{\overline{\mathbf{N}}\} \text { MMd N@): lit. from the places of } \\
\text { rising (> Ziegler) }\end{array}$ \\
\hline $41: 2$ & 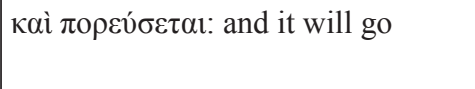 & $\begin{array}{l}\text { dYW dCoYd } \overline{2 C} \text { NCW } \overline{4}: \text { and it followed him } \\
(>\text { Ziegler) }\end{array}$ \\
\hline $41: 3$ & $\delta 1 \varepsilon \lambda \varepsilon v ́ \sigma \varepsilon \tau \alpha 1:$ they will pass through & Namoow€: lit. [they] will walk ${ }^{126}$ (> Ziegler) \\
\hline $41: 4$ & 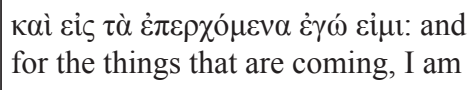 & $\begin{array}{l}\text { aY } \omega \overline{\mathbf{M N}}<\mathbf{N}>\mathbf{C \omega C} \text { aNOK ON } \Pi \epsilon: \text { and } \\
\text { afterward I am as well ( }>\text { Ziegler) }\end{array}$ \\
\hline 41:9 & $\begin{array}{l}\dot{\varepsilon} \kappa \tau \tilde{\omega} \nu \sigma \kappa o \pi i \tilde{\omega} \nu \alpha \hat{\tau} \tau \tilde{\eta} s: \text { from its } \\
\text { mountain peaks }\end{array}$ & 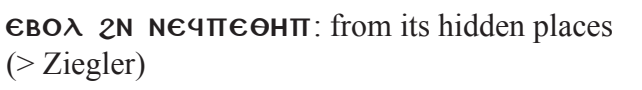 \\
\hline $41: 11$ & $\gamma \alpha \dot{\alpha} \rho$ & $\begin{array}{l}\Delta \epsilon(>\text { Ziegler }) \text { both particles have similar } \\
\text { meanings }\end{array}$ \\
\hline $41: 17$ & 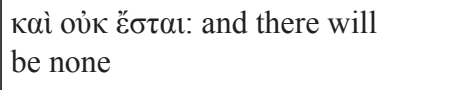 & 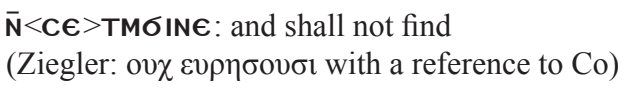 \\
\hline $41: 18$ & $\begin{array}{l}\dot{\varepsilon} v \mu \varepsilon \varepsilon^{\sigma} \omega \pi \varepsilon \delta \dot{c} \omega v: \text { in the midst of the } \\
\text { plains }\end{array}$ & 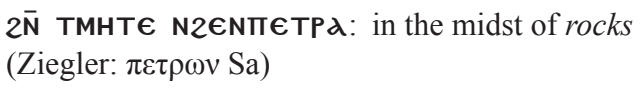 \\
\hline $41: 19$ & $\lambda \varepsilon \cup ́ \kappa \eta v:$ a white poplar & $\begin{array}{l}\text { оҮпєҮКн: a pine (Ziegler: } \pi \varepsilon v \kappa \eta \nu \\
233407538 \mathrm{Sa} \text { ) }\end{array}$ \\
\hline $41: 23$ & $\alpha \dot{\alpha} \alpha \alpha \gamma \gamma \varepsilon i ́ \lambda \alpha \tau \varepsilon:$ proclaim! & 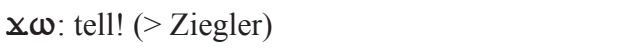 \\
\hline $41: 29$ & 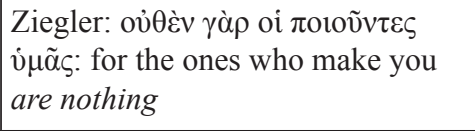 & 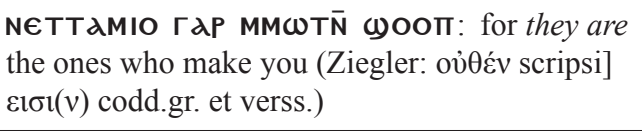 \\
\hline $41: 29$ & 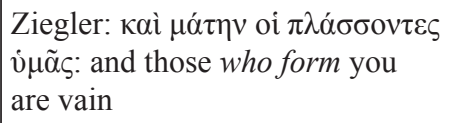 & 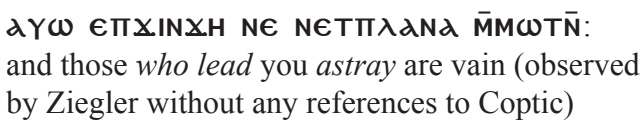 \\
\hline
\end{tabular}


Table 4 . Changes of prepositions

\begin{tabular}{|c|c|c|}
\hline $41: 2$ & eiऽ $\gamma \tilde{\eta} v:$ in the earth & 2їхм пК 2 2: lit. upon the earth (> Ziegler) \\
\hline $41: 18$ & 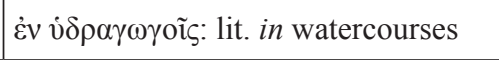 & N2€NBO: as watercourses (> Ziegler) \\
\hline $41: 19$ & 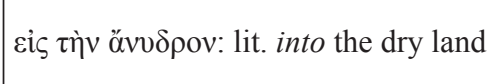 & $\begin{array}{l}2 \overline{\mathbf{M}} \text { ПКд2 } € \text { Єовє: lit. in the dry land } \\
\text { (> Ziegler) }\end{array}$ \\
\hline
\end{tabular}

Table 5. Changes of articles

\begin{tabular}{|c|c|c|}
\hline $41: 12$ & 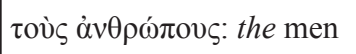 & €үРФмє: $a$ man (> Ziegler) \\
\hline $41: 20$ & $\chi$ \&ìp: lit. $a$ hand & $\begin{array}{l}\text { TбIX: the hand (Ziegler: pr. H } 403^{\prime} \text { without } \\
\text { any references to Coptic) }\end{array}$ \\
\hline
\end{tabular}

Table 6. Changes in word order

\begin{tabular}{|c|c|c|}
\hline $41: 2$ & 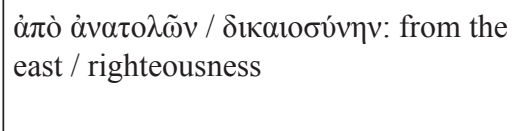 & 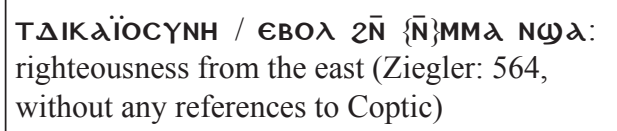 \\
\hline $41: 2$ & 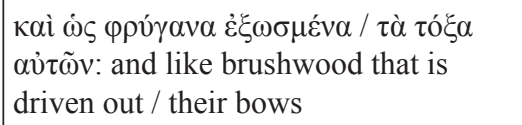 & 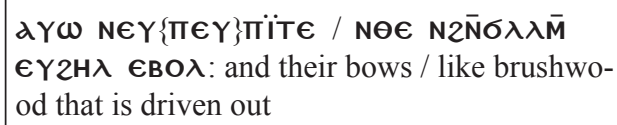 \\
\hline $41: 3$ & 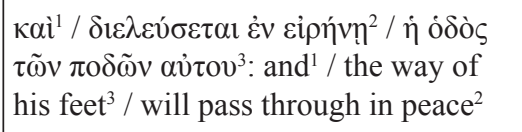 & 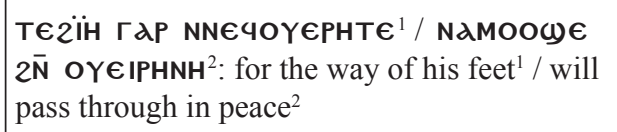 \\
\hline $41: 9$ & 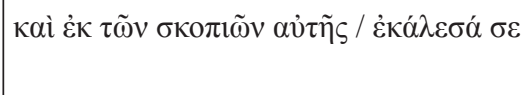 & 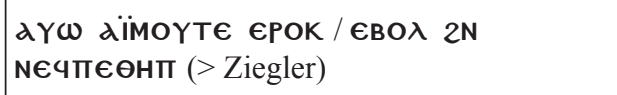 \\
\hline $41: 11$ & 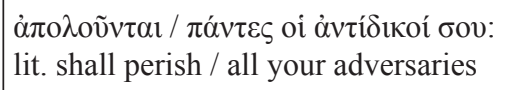 & NEXגX€ THPOY / NATAKO (> Ziegler) \\
\hline $41: 12$ & 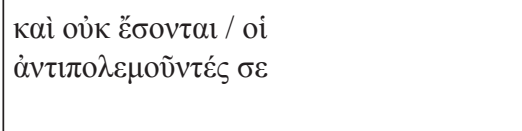 & 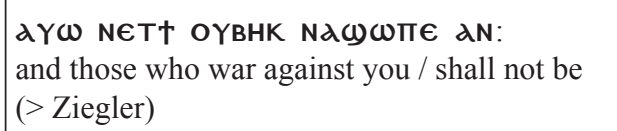 \\
\hline $41: 15$ & 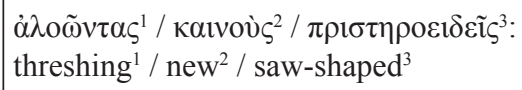 & 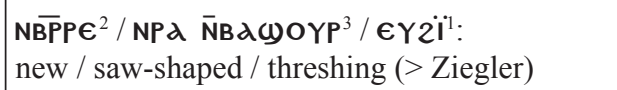 \\
\hline $41: 16$ & $\begin{array}{l}\dot{\omega} \varsigma \chi v o v ̃ v^{1} / \theta \eta \dot{\sigma} \sigma \varepsilon ı \varsigma^{2}: \text { you shall make } \\
\text { them }^{2} / \text { like dust }\end{array}$ & $\overline{\mathbf{N} \Gamma} \boldsymbol{\alpha} \alpha \boldsymbol{Y}^{2} / \mathbf{N} \Theta €$ NOY $\boldsymbol{\omega}<\mathbf{O}>\boldsymbol{\epsilon} \mathbf{I} \boldsymbol{\omega}^{1}$ ( $>$ Ziegler $)$ \\
\hline
\end{tabular}




\begin{tabular}{|c|c|c|}
\hline $41: 17$ & 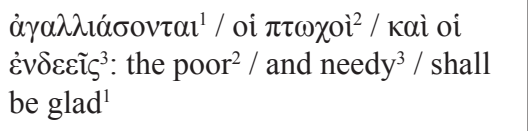 & 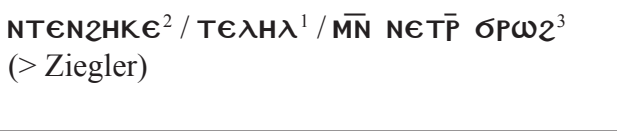 \\
\hline $41: 17$ & 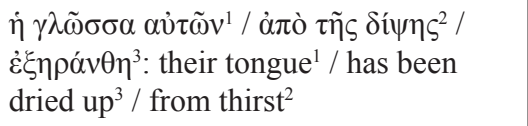 & 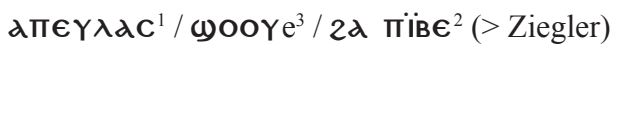 \\
\hline $41: 18$ & 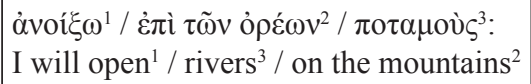 & 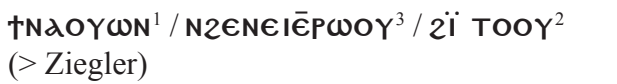 \\
\hline $41: 18$ & 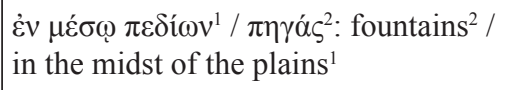 & 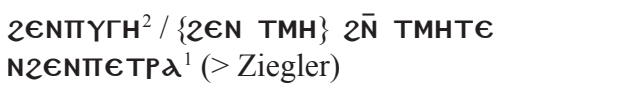 \\
\hline 41:19 & 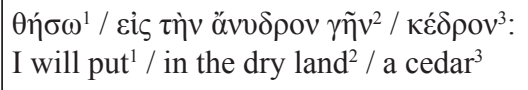 & 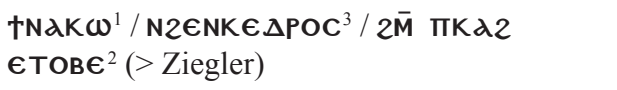 \\
\hline $41: 22$ & 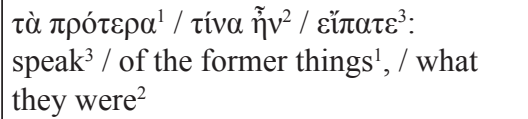 & dXIC $X \epsilon^{3} /$ OY $N \epsilon^{2} / \mathbf{N} \omega O P \bar{\Pi}^{1}$ (> Ziegler) \\
\hline $41: 22$ & 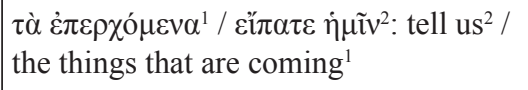 & $X \omega \mathbf{N A N}^{2} / \mathbf{N N} \epsilon \mathrm{TNH}^{1}{ }^{1}$ (> Ziegler) \\
\hline $41: 24$ & $\begin{array}{l}\dot{\varepsilon} \kappa \gamma \tilde{\eta} \varsigma^{1} / \beta \delta \dot{\varepsilon} \lambda v \gamma \mu \alpha \dot{\varepsilon} \xi \varepsilon \lambda \varepsilon \dot{\varepsilon} \xi \alpha v \tau o \text { v } \mu \tilde{\alpha} \varsigma^{2}: \\
\text { From the earth }{ }^{1} . / \text { They have chosen } \\
\text { you as an abomination }{ }^{2}\end{array}$ & 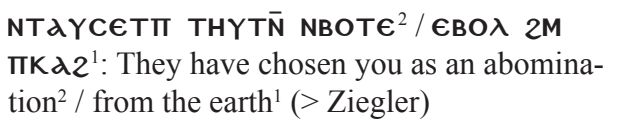 \\
\hline $41: 27$ & $\begin{array}{l}\alpha \rho \chi \eta े v^{1} / \Sigma 1 \omega v^{2} / \delta \omega \sigma \sigma \omega^{3}: \text { I will give }{ }^{3} / \\
\text { dominion }^{1} \text { / to Sion }\end{array}$ & 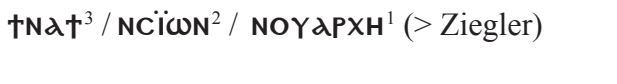 \\
\hline $41: 28$ & 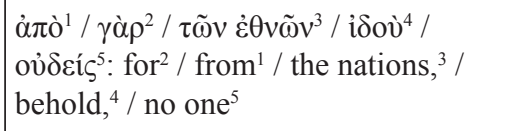 & 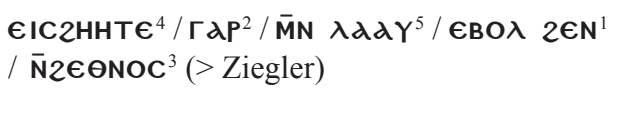 \\
\hline $41: 28$ & 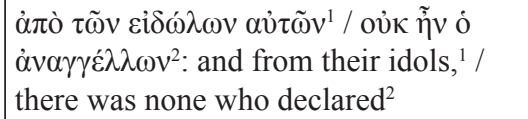 & $\begin{array}{l}\overline{M N} \Pi \epsilon T<T>\text { MMO }^{2} / \bar{\epsilon} B O \lambda 2 N \\
N \epsilon Y \epsilon I \Delta \omega \lambda \mathbf{N}^{1}(>\text { Ziegler })\end{array}$ \\
\hline
\end{tabular}


Table 7. Semantic changes

\begin{tabular}{|c|c|c|}
\hline $41: 2$ & 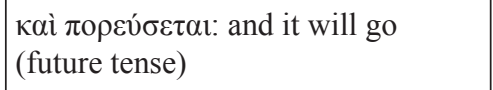 & 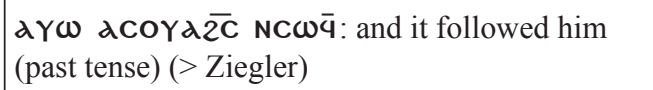 \\
\hline $41: 4$ & $\begin{array}{l}\dot{\alpha} \pi \text { ò } \gamma \varepsilon v \varepsilon \tilde{\omega} \nu \alpha \dot{\alpha} \chi \tilde{\eta} \varsigma: \text { from the begin- } \\
\text { ning of generations }\end{array}$ & 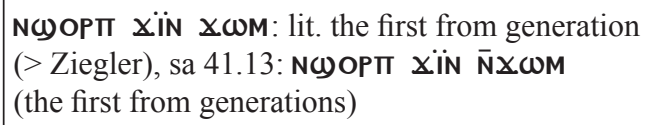 \\
\hline $41: 5$ & $\begin{array}{l}\tau \grave{\alpha} \text { ök } \rho \alpha \tilde{\eta} \varsigma \gamma \tilde{\eta} \varsigma: \text { the ends of } \\
\text { the earth }\end{array}$ & 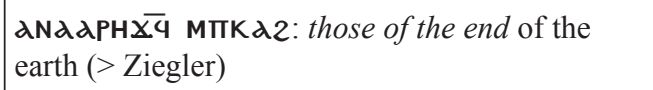 \\
\hline $41: 6$ & 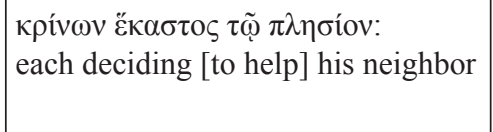 & 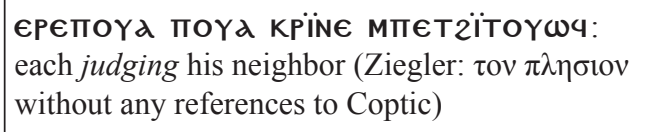 \\
\hline $41: 7$ & 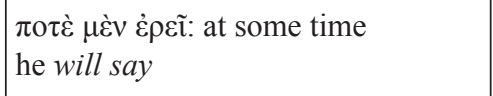 & 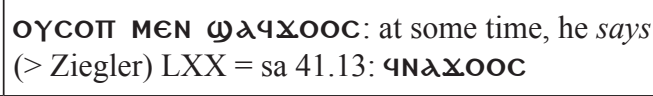 \\
\hline $41: 7$ & 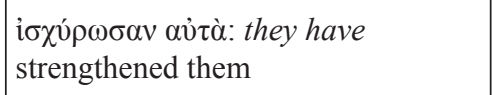 & $\begin{array}{l}\text { d4TגXPooY: he has strengthened them } \\
\text { (> Ziegler) }\end{array}$ \\
\hline 41:9 & $\dot{\alpha} \pi$ ' ök $\omega \omega v$ : from the ends & 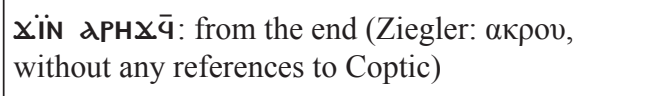 \\
\hline $41: 12$ & $\tau o \nu ̀ \varsigma \alpha \dot{\alpha} \theta \rho \omega ́ \pi \circ v \varsigma:$ the men (plural) & ЄYPФмє: a man (singular) (> Ziegler) \\
\hline $41: 19$ & 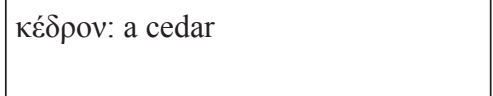 & 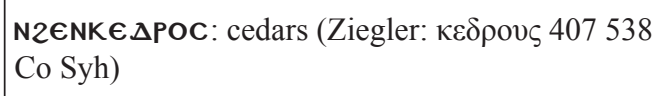 \\
\hline $41: 22$ & 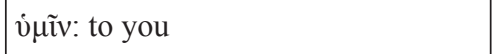 & NdN: to us (Ziegler: $\eta \mu \mathrm{v} v$ with a reference to $\mathrm{Sa}$ ) \\
\hline $41: 23$ & $\varepsilon \tilde{v} \pi \circ \eta \dot{\sigma} \sigma \alpha \tau \varepsilon:$ do good (adverb form) & $\begin{array}{l}\text { aPI ח€TNANOY4: lit. do what is good } \\
\text { (> Ziegler) }\end{array}$ \\
\hline $41: 28$ & 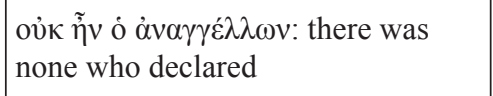 & $\begin{array}{l}\overline{\mathbf{M N}} \text { пє } \mathbf{T}<\mathbf{T}>\text { dMO: lit. there } i \text { is none who declares } \\
(>\text { Ziegler) }\end{array}$ \\
\hline
\end{tabular}

Table 8. Greek words in the Coptic text

\begin{tabular}{|c|c|c|}
\hline $41: 8$ & $\mathrm{~A} \beta \rho \alpha \alpha \mu$ & АВРАСАM \\
\hline $41: 27$ & $\dot{\alpha} \rho \chi \eta ்$ & APXH \\
\hline $41: 1.25$ & $\ddot{\alpha} \rho \chi \omega v$ & APXWN \\
\hline $41: 6.10 .14$ & $\beta о \eta \theta \varepsilon ́ \omega$ & вонөєї, в<о> $>$ нөє \\
\hline \begin{tabular}{|l}
$41: 1.10(2 \mathrm{x})$ \\
12.17 .26 .28 .29
\end{tabular} & 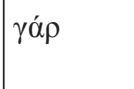 & $\Gamma d P$ \\
\hline
\end{tabular}




\begin{tabular}{|c|c|c|}
\hline $41: 8.11 .16 .25$ & $\delta \varepsilon$ & $\Delta \epsilon$ \\
\hline $41: 2$ & $\delta 1 \kappa \alpha 10 \sigma v ́ v \eta$ & $\Delta I K$ גїOCYNH \\
\hline $41: 2.5 .28$ & $\ddot{\varepsilon} \theta v \circ \varsigma$ & $2 € \Theta N O C$ \\
\hline $41: 28$ & $\varepsilon i \delta \omega \lambda \circ \mathrm{v}$ & $\epsilon I \Delta \omega \lambda O N$ \\
\hline $41: 3$ & 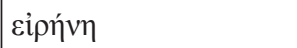 & EIPHNH \\
\hline $41: 18$ & $\varepsilon \ddot{\lambda} \mathrm{o \zeta}$ & $2 € \lambda O C$ \\
\hline $41: 4$ & 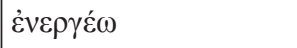 & ЄN€PГЄI \\
\hline $41: 24$ & $\dot{\varepsilon} \rho \gamma \alpha \sigma i ́ \alpha$ & ЄРГасїд \\
\hline $41: 18$ & 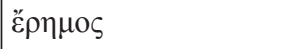 & ЄРHMOC \\
\hline $41: 16$ & 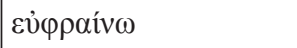 & ЄYФРАN€ \\
\hline $41: 22$ & $\ddot{\eta}$ & H \\
\hline $41: 8.14 .21$ & $\operatorname{I} \alpha \kappa \omega \beta$ & $\ddot{I} \lambda K \omega \mathrm{B}$ \\
\hline $41: 27$ & I $\varepsilon \rho o v \sigma \alpha \lambda \eta \mu$ & $\theta । \overline{\lambda H M}$ \\
\hline $\begin{array}{l}41: 8.14(2 x) \\
16.17 .20\end{array}$ & I $\sigma \rho \alpha \eta \lambda$ & $\overline{\Pi \mathrm{IH} \lambda}$ \\
\hline 41:19 & 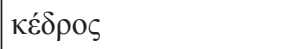 & $K \in \Delta P O C$ \\
\hline $41: 25(2 x)$ & $\kappa \varepsilon \rho \alpha \mu \varepsilon v ́ \varsigma$ & K€PдM€YC \\
\hline $41: 6$ & 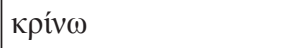 & KPINE \\
\hline $41: 19$ & $\kappa v \pi \alpha ́ \rho 1 \sigma \sigma o \varsigma$ & Күпарї̈CC \\
\hline $41: 19$ & $\lambda \varepsilon v ́ \kappa \eta$ & пєҮКн \\
\hline $41: 19$ & $\mu \nu \rho \sigma i ́ v \eta$ & MOPCYNH \\
\hline $41: 1$ & vच̃бos & NHCOC \\
\hline $41: 26$ & ov̉ $\delta \varepsilon$ & OY $\Delta \epsilon$ \\
\hline $41: 18$ & 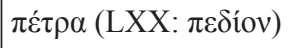 & $\pi \epsilon T P d$ \\
\hline $41: 18$ & $\pi \eta \gamma \eta ́$ & ПҮГГн \\
\hline $41: 10.29$ & $\pi \lambda \alpha v \alpha ́ \omega$ & $\Pi \lambda \lambda \mathrm{N} \alpha$ \\
\hline $41: 19$ & $\pi v ́ \xi o s$ & TYZIINON \\
\hline $41: 27$ & $\Sigma 1 \omega v$ & CïLN \\
\hline $41: 8$ & $\sigma \pi \varepsilon \dot{\varepsilon} \rho \mu \alpha$ & СпєРMd \\
\hline $41: 1$ & $\tau o ́ \tau \varepsilon$ & тотє \\
\hline
\end{tabular}




\section{The Analysis of Selected Philological Questions Found in Isa 41}

The last part of the paper includes an analysis of selected philological questions found in the second chapter of Deutero-Isaiah. They mainly concern two areas. The first is differences between manuscript sa 52 and other witnesses appearing in the critical apparatus. The other shows the way the Coptic translator read the Greek text.

\section{Isa 41:1}

Manuscript sa 41.13 contains a slightly modified version: $2 \overline{\mathbf{N}}$ т€үбом, which should be rendered as in their strength. Since the text of the LXX has the direct object i $\sigma \chi v v$ without any preposition it would be better to accept the Coptic translation found in our manuscript sa 52: NT€YбOM.

\section{Isa 41:2}

Our manuscript has the form $\{\overline{\mathbf{N}}\}$ MMd $\mathbf{N} \boldsymbol{~}$ d, which literally means "the places of the east" or "the easts." This form perfectly agrees with the Greek text that reads $\dot{\alpha} \pi \hat{\alpha} \dot{\alpha} v \alpha \tau \partial \tilde{\omega} v$, where the word "east" was used in plural. At this point, it is worth noting two things. Firstly, in Isa 11:11, we have the identical notation $\{\overline{\mathbf{N}}\} \mathbf{M M d}$ $\mathbf{N} \boldsymbol{d} \mathbf{d}$, where the scribe also added the unnecessary letter $\overline{\mathbf{N}}$. Secondly, Isa 11:11 has the precise phrase $\{\overline{\mathbf{N}}\}$ MMd $\mathbf{N} \omega \mathbf{\alpha}$ MTPH. Consequently, we can undoubtedly read about "the places of the sunrise." The plural form might have been used to express "sunrise." Isa 41:2 does not contain this clarification: MTPH. Thus, we have two interpretations: either the author speaks in general that God "has roused righteousness from the east" (having in mind King Cyrus the Great) or refers to the righteousness roused in different places in the east. Therefore, the author would have referred to the various places related to Cyrus, for example Elam conquered by him in $558 \mathrm{BC}$ or Babylon seized in $539 \mathrm{BC}$. A question arises whether the Coptic translator could have known the history of Cyrus's conquests. It seems probable, especially if we consider the Persian king's plans to conquer Egypt. In the Egyptian circles, there could have been narratives about Cyrus and his threats against Egypt. Summing up, the plural form MMd $N \omega d$ used in our manuscript may have resulted from the historical knowledge of Cyrus's deeds or may have been a plurale tantum used to describe "the east" or may simply have been a literal translation of the Greek $\alpha v \alpha \tau o \lambda \tilde{\omega} v$.

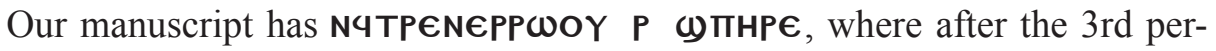
son singular masculine conjunctive NG- occurs the causative infinitive TPE-, followed by the noun $\in$ PPWOY preceded by the plural article $\mathbf{N}-$. The second 
part P $\boldsymbol{\omega}$ пннє is a composed verbal form that means "be amazed". ${ }^{126}$ In manuscript sa 41.13, we come across the slightly different form N4TP€ $\bar{N} \bar{N} P P \omega O Y$, in which the noun with the article (NPPWOY) is preceded by still another $\overline{\mathbf{N}}$. Here we are probably dealing with a common scribal error (dittography), especially that the edition of the same manuscript worked out by Winstedt contains only one $\mathbf{N}$ (N4TPENPPWOY). It is not very probable that the scribe added the letter $\overline{\mathbf{N}}$, intending to treat the noun NPPWOY as a direct object. It would have been a very non-typical construction with a causative infinitive. "Like the other bases, TP€is followed by entity term and infinitive." 127 Hence N4TP€N€PPФOY PФாнР€ occurring in our manuscript is by all means correct.

In manuscript sa 52, there is the form N€үாєҮпїєє. Here we have the noun пїє, meaning "a bow," uniquely preceded by two different possessive articles. One of them (N€Y-) has a plural reference and together with the noun assumes the meaning "their bows." The other (п€Y-) points to the singular form "their bow." Thus, the reader must choose between N€үாїє and пєүпїє . Since the

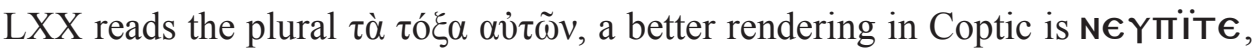
which follows the reading of manuscript sa 41.13 . The edition of the manuscript

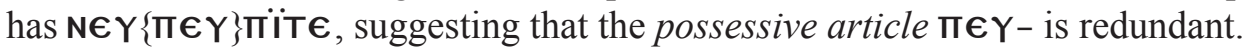

\section{Isa 41:6}

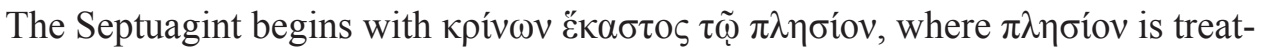

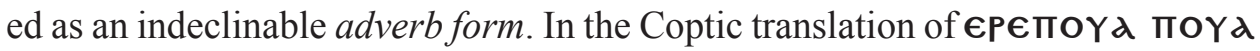

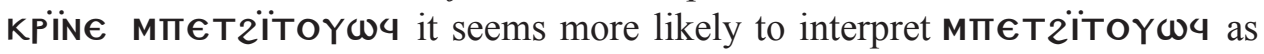
the direct object of the verb KPiN€, used in its basic sense "to judge." We could assume that the Coptic version agrees with some manuscripts of the LXX (including 534 and 538), which interpret $\pi \lambda \eta \sigma i ́ o v$ as a nominal form changing the article to the accusativus ( $\tau$ òv $\pi \lambda \eta \sigma i ́ o v$ ).

The analysis of the Greek text shows that the author of the LXX interprets

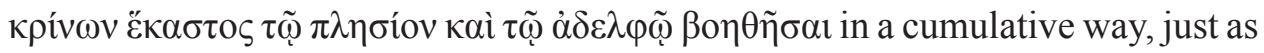
it was rendered in NETS: "each deciding to help his neighbor and his brother." On the other hand, the Coptic translator explicitly divides the sentence into two parts.

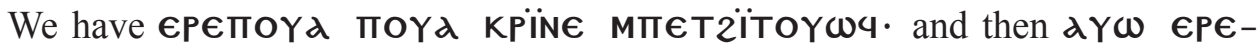
поҮд поҮд вонөєі єாєчCON, where the subject поҮд поҮ by the conversion of $€ \mathbf{E} \epsilon-$ is repeated. ${ }^{128}$ The division of the Coptic text is also

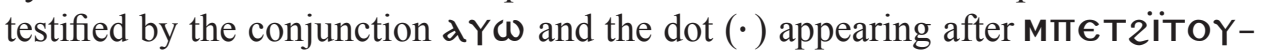

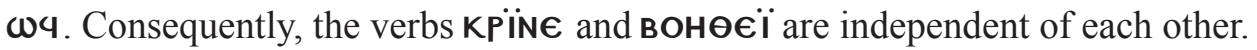

126 Crum, Coptic Dictionary, 581b.

127 Layton, Coptic Grammar, § 359.

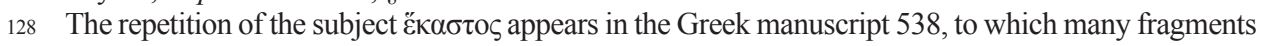
of the Coptic manuscript sa 52 are equivalent. 
The Coptic version semantically differs from the text of the LXX. At first, it says that "everyone judges his neighbor" and then that "everyone helps his brother." In the context of the preceding verses, this behaviour might be an image of some confusion arisen among foreign nations who witnessed the conquests of Cyrus. Since the content of the next verse - Isa 41:7 is related to Isa 40:19, we could assume that Isa 41:6 should also be interpreted in the context of the previous chapter (Isa 40). A more detailed exegetical analysis of Isa $40-41$ could answer this question.

\section{Isa 41:10}

In the Coptic translation, we find a longer version of this verse. After translating the Greek $\mu \eta \dot{\eta} \pi \lambda \alpha v \tilde{\omega}$, the Sahidic version adds words that can be rendered as In you I will be glorified. But I said: "I have labored vainly [and] for nothing.

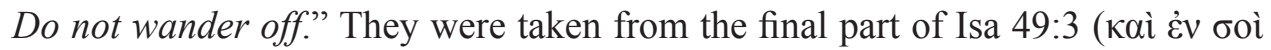

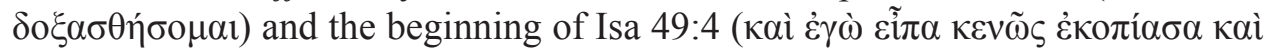

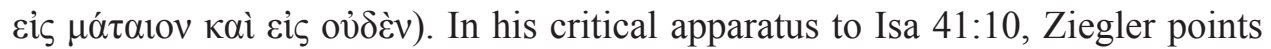
out that the longer version of the verse begins after the 2 nd person pronoun $\sigma o v$, which is not true. The longer version begins earlier, namely after the imperative $\mu \eta \grave{~} \pi \lambda \alpha \nu \tilde{\omega}$.

\section{Isa 41:12}

In the Greek version of the LXX we can hardly find the verb $\pi \alpha \rho o v \varepsilon \varepsilon^{\prime} \omega$ meaning "to behave ill at wine, to insult, to rage against." ${ }^{22}$ Its Coptic equivalent is also rare. A verb related to "drinking too much" could be $\uparrow 2 €,{ }^{130}$ but its meaning refers to a violent action. The Coptic translator used the general KIM $\boldsymbol{\epsilon}$ - , which means "to move" and "be moved," 131 also referring to violence. ${ }^{132} \mathrm{Al}-$ though the construction ЄTKIM ЄPOK does not exactly correspond to the Greek

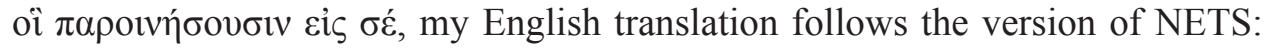
"who shall treat you violently."

\section{Isa 41:16}

The final part of the verse in the LXX contains $\dot{\varepsilon} v \tau o \tilde{i} \varsigma \dot{\alpha} \gamma i$ or $\varsigma$ I $\sigma \rho \propto \eta \lambda$ meaning "in the holy things of Israel." 133 The Coptic rendering is faithful to the Greek

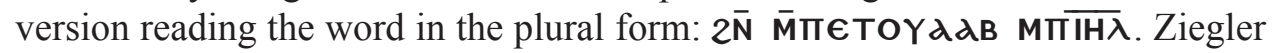
gives examples of manuscripts containing the singular form: $\varepsilon v \tau \omega \alpha \gamma 1 \omega$ ("in

\footnotetext{
129 Lust, Lexicon, 473a.

130 Crum, Coptic Dictionary, 456b.

131 Crum, Coptic Dictionary, 108a.

132 Cf. Crum, Coptic Dictionary, 109a.

133 A probable alternative translation is: "in the holy ones of Israel," which has been given in the footnote in NETS (p. 855).
} 
the holy thing ${ }^{134}$ of Israel"). Yet, he notes that the singular form occurs in the Coptic manuscripts, which is not true! Our manuscript sa 52 clearly reads $\overline{\mathbf{M}} \Pi \epsilon-$ тоYдdв, and not $\bar{\pi} п \epsilon т о \gamma д ג B$, thus being a faithful translation of the Greek

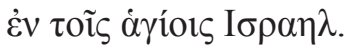

\section{Isa 41:17}

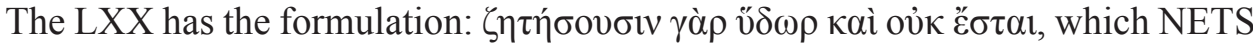
translates as for they shall seek water, and there will be none. The Coptic translation in sa 52 reads this fragment as a slightly changed construction CENd $\omega$ IN $€$

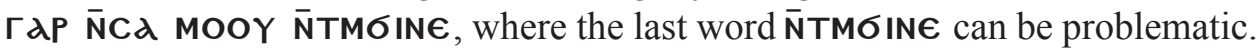
It consists of the verb $\sigma \mathbf{I N} \epsilon$, meaning "to find" 135 preceded by the negative $-\mathrm{T} \overline{\mathrm{M}}$ and the letter $\mathbf{N}-$, which could create the so-called attributive construction. The whole formulation could then mean for they shall seek water, which cannot be found.

Ziegler, in his critical apparatus of the LXX, states that the Greek manuscript

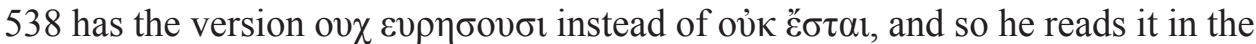
future tense: they will not find. At the same time, he remarks that this version appears in the Coptic texts. In order to accept Ziegler's remark, we should slightly modify the verbal form $\overline{\mathbf{N}} T \mathbf{T} \boldsymbol{\text { IIN }} \boldsymbol{\epsilon}$, adding a 3rd person singular subject. We would have $\overline{\mathbf{N}}<\mathbf{C \epsilon}>$ TMOIN€ , which itself is the negated form of the conjunctive. Since in our verse the earlier verbal form was C€Nd $\omega$ IN $€$ (durative future), the conjunctive $\overline{\mathbf{N}}<\mathbf{C} \epsilon>$ TMOIN€ would also assume the meaning of the future tense,

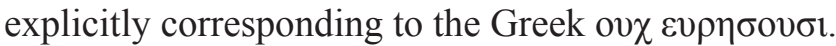

\section{Isa 41:18}

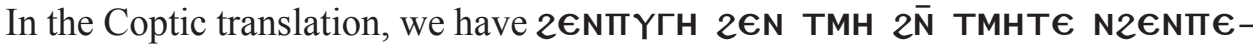
TPd. What is problematic in the translation is $2 \in \mathbf{N} \mathbf{T M H}$, whose literal meaning is "in the urine." ${ }^{136}$ Yet, it does not fit the content of our verse at all. If we omit the problematic words, the verse will become much more logical. The construction $2 € N \Pi Y \Gamma H \quad 2 \bar{N}$ TMHT€ N2€NTT TPd conveys the clear meaning: "fountains in the midst of the rocks." $2 \in \mathbf{N}$ TMH, difficult to translate, may be an instance of dittography since the similar expressions: $2 \in \mathbf{N}$ TMH and $2 \overline{\mathbf{N}}$ TMHT€ occur very close to each other.

It is worth noting that in the text of Proto-Isaiah (Isa 1-39) the scribe always uses $2 \overline{\mathbf{N}}$ TMHT€ (Isa 6:5 and 24:13). After having written $2 € \mathbf{N}$ TMH, he could have realised that it was not his typical form. He left it "unfinished" with

134 Or "in the holy one of Israel."

135 Crum, Coptic Dictionary, 820a.

136 Cf. Crum, Coptic Dictionary, 158a. 
the missing letters $-\mathbf{T} \epsilon$ and began the next line ${ }^{137}$ with his standard formulation $2 \overline{\mathbf{N}}$ TMHTє.

\section{Isa 41:25}

The final $€$ TOYNA2M $\bar{M}$ THYTN can be understood in two ways. Firstly, we can treat $\mathbf{N} 22 \overline{\mathrm{M}}$ as a prenominal form of the verb NOY2M, meaning "be saved." 138 The Coptic construction would consist of the following elements: $\boldsymbol{\epsilon} \mathbf{T}-$, a relative converter, -OY-, a subject ( 3 rd person plural ${ }^{139}$ ), the verb $\mathbf{N} 22 \overline{\mathbf{M}}-$ as well as the 2nd person plural pronoun THYTN, serving as the object of the verb in this construction. Therefore, $€$ TOYNA2 $\bar{M}$ THYTN could be rendered as "you are saved," which does not fit the context of the verse. The verb $\mathrm{N} \lambda 2 \overline{\mathrm{M}}$ would lead us to read "Like potter's clay - even as a potter treading his clay - so you are saved." Being saved "as a potter treading his clay" does not make any sense.

The other way of reading the final $€$ TOYNA2 $\bar{M}$ THYTN would be to divide $\mathrm{N} d 2 \overline{\mathrm{M}}$ into two parts: $-\mathrm{Nd}-$ an infix of the future tense, while $2 \overline{\mathrm{M}}-$ a prenominal form of the verb $2 \omega \mathrm{M}$, meaning "to tread" or "to trample." 140 This interpretation would allow us to read the final part of our verse as "even as a potter treading ${ }^{141}$ his clay - so shall you be trodden down," which obviously makes sense.

\section{Isa 41:28}

Manuscript sa 52 has the notation $\overline{\mathbf{M N}} \Pi \boldsymbol{\Pi} \mathbf{T} \boldsymbol{\text { MMO}}$, where $\overline{\mathbf{M N}}$ - is a statement of non-existence, while the verb TaMo ("to tell," "to inform"142) is preceded by the definite article, singular masculine $\Pi \epsilon-$. We may be astonished by the full form of this article (with the added vowel $\boldsymbol{\epsilon}$ ). The vowel is used when the following word begins with two consonants. Yet, this is not the case with the verb TdMo. We should also remember that in Coptic the definite article never occurs after OY $\overline{\mathbf{N}}$ - or $\mathbf{M} \overline{\mathbf{N}}-$ in the existential sentence. ${ }^{143}$ Consequently, it is wrong to interpret $\Pi \epsilon-$ as an article.

The other possibility could be related to the use of the so-called relative converter $\boldsymbol{\epsilon} \mathbf{T}$. Yet, also in this case, the relative converter could not be preceded by the definite article because of the previously used $\mathbf{M} \overline{\mathbf{N}}-$.

The third, most obvious possibility, is based on the so-called invariable $\Pi \epsilon \mathbf{T}$ rendered as "one who is." 144 There is no article before the invariable $\mathbf{\Pi \epsilon} \mathrm{T}$, and

137 I mean lines 23 and 24 of column b on p. $83 \mathrm{f} .41 \mathrm{r}$.

138 Crum, Coptic Dictionary, 243 b.

139 In this case, the $3 \mathrm{rd}$ person plural pronoun can be treated as signifying the passive voice.

140 Crum, Coptic Dictionary, 674b.

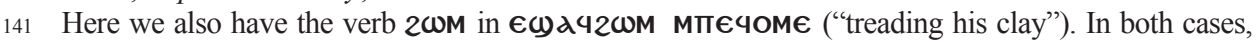

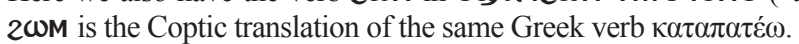

142 Crum, Coptic Dictionary, $413 \mathrm{~b}$.

143 Layton, Coptic Grammar, $\$ 322$.

144 Layton, Coptic Grammar, § 110. 
so it can be preceded by the form oY $\overline{\mathbf{N}}-$ or $\mathbf{M} \overline{\mathbf{N}}-$. However, in our expression, $\overline{M N}$ пєТАMO, the consonant $\mathrm{T}$ would be missing. The correct notation must have been $\overline{\mathbf{M N}} \boldsymbol{\pi} \boldsymbol{\epsilon} \mathbf{T}<\mathbf{T}>\mathbf{d} \mathbf{M O}$. The lack of $\mathbf{T}$ could be treated as an instance of haplography.

As for Isa 41:28, we can compare it with CLM 1604, which, however, has the same reading as manuscript sa 52 . Accordingly, it is not helpful in explaining the origin of the construction $\overline{M N}$ пєТАMO.

\section{Conclusion}

The edition of the second chapter of Deutero-Isaiah, included in this paper, shows the importance and uniqueness of manuscript sa 52, which has not been published as a whole yet. Our manuscript contains the complete Sahidic text of Isa 41, which can be seen especially in verses 11-27, which currently can be found only in sa 52. Let us hope that the presentation of the Sahidic text of Isa 41, its translation and comparison with the Septuagint as well as the detailed analysis of the difficult philological questions will contribute to greater knowledge and a better understanding of the biblical message and historical interpretation of the Book of the Prophet Isaiah.

\section{Bibliography}

Amélineau, É., „Fragments de la version thébaine de l'Écriture (Ancien Testament),” Recueil de Travaux Relatifs à la Philologie et à l'Archéologie Égyptiennes et Assyriennes 9 (1887) 101-130. Balestri, P.J., Sacrorum Bibliorum Fragmenta Copto-Sahidica Musei Borgiani. III. Novum Testamentum (Roma: Typographia Polyglotta S. C. de Propaganda Fide 1904).

Bąk, T., „A Critical Edition and Philological Analysis of the First Chapter of Deutero-Isaiah (Isa 40) on the Basis of the Coptic Manuscript sa 52 (M 568) in Light of Other Coptic Manuscripts Written in the Sahidic Dialect and the Greek Text of the Septuagint," The Biblical Annals 9/1 (2019) 73-100 (=Isa 40).

Bąk, T., „Koptyjski przekład Iz 1-39 w manuskrypcie sa 52 (M 568) z VIII w.,” The Biblical Annals 5/2 (2015) 289-305.

Bąk, T., Il Proto-Isaia in copto-saidico. Edizione critica sulla base di sa 52 (M 568) e di altri testimoni. Estratto della dissertazione per il Dottorato in Studi dell'Oriente Antico (Roma: Pontificio Instituto Biblico, Facoltà Orientalistica 2014).

Ciasca, A., Sacrorum Bibliorum fragmenta copto-sahidica Musei Borgiani iussu et sumptibus S. Congregationis de Propaganda Fide studio P. Augustini Ciasca ordinis Eremitarum S. Agostini edita (Roma: Typis S. Congregationis de Propaganda Fide 1885-1889) I-II. 
Crum, W.E., Catalogue of the Coptic Manuscripts in the British Museum (London: British Museum 1905).

Crum, W.E., A Coptic Dictionary (Oxford: Clarendon Press 1939) (reprint: Eugene, OR: Wipf \& Stock 2005).

Crum, W.E. - Winlock, H.E., The Monastery of Epiphanius at Thebes. I. The Archeological Material by H.E. Winlock. The Literary Material by W.E. Crum (New York: The Metropolitan Museum of Art 1926).

Crum, W.E. - Evelyn White, H.G., The Monastery of Epiphanius at Thebes. II. Coptic Ostraca and Papyri Edited with Translations and Commentaries by W.E. Crum. Greek Ostraca and Papyri Edited with Translations and Commentaries by H.G. Evelyn White (New York: The Metropolitan Museum of Art 1926).

A New English Translation of the Septuagint (ed. A. Pietersma -B.G. Wright) (New York: Oxford University Press 2007) (=NETS)

Feder, F., Biblia Sahidica. Ieremias, Lamentationes (Threni), Epistula Ieremiae et Baruch (Texte und Untersuchungen zur Geschichte der altchristlichen Literatur 147; Berlin - New York: Gruyter 2002).

Hebbelynck, A., „Les manuscrits coptes-sahidiques du «Monastère Blanc». Recherches sur les fragments complémentaires de la Collection Borgia. I. Fragments de l'Ancien Testament" Muséon 12 (1911) 1-64.

Horner, G.W., The Coptic Version of the New Testament in the Southern Dialect, Otherwise Called Sahidic and Thebaic, with Introduction, Critical Apparatus, and Literal English Translation. III. The Gospel of S. John (Oxford: Clarendon Press 1911).

Hurtado, L., The Earliest Christian Artifacts: Manuscripts and Christian Origins (Grand Rapids, MI: Eerdmans 2006).

Hyvernat, H., „Étude sur les versions coptes de la Bible. II. - Ce qui nous est parvenu des versions égyptiennes," Revue Biblique 5 (1896) 540-569.

Lacau, P., „Textes de l'Ancien Testament en copte sahidique,” Recueil de Travaux Relatifs à la Philology et à l'Archéologie Égyptiennes et Assyriennes. Nouvelle Série 7 (1901) 103-124.

Layton, B., A Coptic Grammar. With Chrestomathy and Glossary. Sahidic Dialect. Second Edition, Revised and Expanded. With an Index of Citations (Wiesbaden: Harrassowitz Verlag 2004).

Lust, J. - Eynikel, E. - Hauspie K., Greek-English Lexicon of the Septuagint (Stuttgart: Deutsche Bibelgesellschaft 2003).

Nagel, P., „Studien zur Textüberlieferung des sahidishen Alten Testaments,” Zeitschrift für Ägyptische Sprache und Altertumskunde 111 (1984) 138-164.

Nagel, P., „Editionen koptischer Bibeltexte seit Till 1960,” Archiv für Papyrusforschung 35 (1990) 43-100.

Rahlfs, A., Die alttestamentlichen Lektionen der griechischen Kirche (Mitteilungen des Septuaginta-Unternehmens der Königlichen Gesellschaft der Wissenschaften zu Göttingen 5; Berlin: Weidmannsche 1915).

Schleifer, J., Sahidische Bibel-Fragmente aus dem British Museum zu London (Sitzungsberichte der Kaiserlichen Akademie der Wissenschaften in Wien. Philosophisch-Historische Klasse 162/6; Wien: Hölder 1909). 
Schmitz, F.J. - Mink, G., Liste der Koptischen Handschriften des Neuen Testaments. I. Die sahidischen Handschriften der Evangelien (Arbeiten zur Neutestamentlichen Textforschung 15; Berlin - New York: Gruyter 1991) 2/2.

Schüssler, K., Das sahidische Alte und Neue Testament: sa 21-48 (red. K. Schüssler) (Biblia Coptica 1/1; Wiesbaden: Harrassowitz 1996).

Schüssler, K., Das sahidische Alte und Neue Testament: sa 93-120 (red. K. Schüssler) (Biblia Coptica 1/4; Wiesbaden: Harrassowitz 2000).

Schüssler, K., Das sahidische Alte und Neue Testament: sa 185-260 (red. K. Schüssler) (Biblia Coptica 2/2; Wiesbaden: Harrassowitz 2015).

Till, W.C., „Papyrussammlung der Nationalbibliothek in Wien. Katalog der koptischen Bibelbruchstücke. Die Pergamente," Zeitschrift für die neutestamentliche Wissenschaft 39 (1940) 1-57.

Till, W.C., „La séparation des mots en copte”, Bulletin de l'Institut d'Archéologie Orientale 60 (1960) 151-170.

Vaschalde, A., „Ce qui a été publié des versions coptes de la Bible,” Revue Biblique 29 (1920) 241-258.

Winstedt, E.O., „Some Unpublished Sahidic Fragments of the Old Testament,” The Journal of Theological Studies 10 (1909) 233-254.

Ziegler, J. (ed.), Septuaginta. Vetus Testamentum Graecum. Auctoritate Societatis Litterarum Gottingensis editum. XIV. Isaias (Göttingen: Vandenhoeck \& Ruprecht 1939).

Zoega, G., Catalogus codicum copticorum manu scriptorum qui in museo Borgiano velitris adservantur (Roma: Typis Sacrae Congregationis de Propaganda Fide 1810). 
